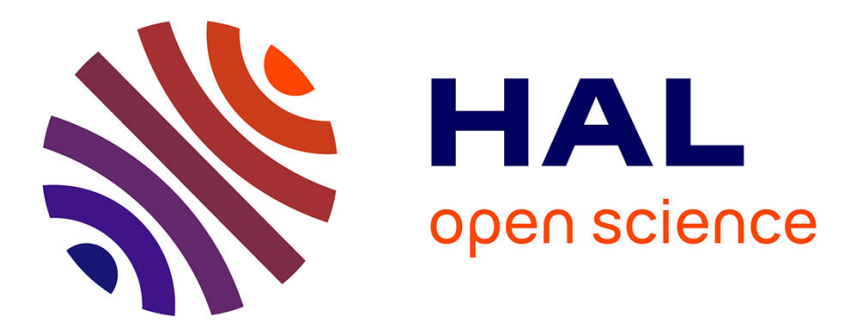

\title{
Euro Area and US external adjustment: The role of commodity prices and Emerging Market shocks
}

Massimo Giovannini, Stefan Hohberger, Robert Kollmann, Marco Ratto, Werner Roeger, Lukas Vogel

\section{To cite this version:}

Massimo Giovannini, Stefan Hohberger, Robert Kollmann, Marco Ratto, Werner Roeger, et al.. Euro Area and US external adjustment: The role of commodity prices and Emerging Market shocks. Journal of International Money and Finance, 2019, 94, pp.183 - 205. 10.1016/j.jimonfin.2019.01.014 . hal03486958

\section{HAL Id: hal-03486958 \\ https://hal.science/hal-03486958}

Submitted on 20 Dec 2021

HAL is a multi-disciplinary open access archive for the deposit and dissemination of scientific research documents, whether they are published or not. The documents may come from teaching and research institutions in France or abroad, or from public or private research centers.
L'archive ouverte pluridisciplinaire HAL, est destinée au dépôt et à la diffusion de documents scientifiques de niveau recherche, publiés ou non, émanant des établissements d'enseignement et de recherche français ou étrangers, des laboratoires publics ou privés.

\section{(ㄷ)(1) $\$$}

Distributed under a Creative Commons Attribution - NonCommerciall 4.0 International 


\title{
Euro Area and U.S. External Adjustment: The Role of Commodity Prices and Emerging Market Shocks
}

\author{
August 6, 2018 \\ Massimo Giovannini (European Commission, Joint Research Centre) \\ Stefan Hohberger (European Commission, Joint Research Centre) \\ Robert Kollmann (ECARES, Université Libre de Bruxelles and CEPR) ${ }^{(*)}$ \\ Marco Ratto (European Commission, Joint Research Centre) \\ Werner Roeger (European Commission, DG ECFIN) \\ Lukas Vogel (European Commission, DG ECFIN)
}

The trade balances of the Euro Area (EA) and of the US have improved markedly after the Global Financial Crisis. This paper quantifies the drivers of EA and US economic fluctuations and external adjustment, using an estimated (1999-2017) three-region (US, EA, rest of world) DSGE model with trade in manufactured goods and in commodities. In the model, commodity prices reflect global demand and supply conditions. The paper highlights the key contribution of the post-crisis collapse in commodity prices for the EA and US trade balance reversal. Aggregate demand shocks originating in Emerging Markets too had a significant impact on EA and US trade balances. The broader lesson of this paper is that Emerging Markets and commodity shocks are major drivers of advanced countries' trade balances and terms of trade.

JEL Codes: F2,F3,F4

Keywords: EA and US external adjustment, commodity markets, emerging markets.

\footnotetext{
${ }^{(*)}$ Corresponding author. Address: Prof. R. Kollmann, ECARES, CP114, ULB, 50 Av. Roosevelt, 1050 Brussels, Belgium; robert_kollmann@yahoo.com. This paper was prepared for the conference 'International Financial Integration in a Changing Policy Context' at the European Commission (March 1-2, 2018). We are very grateful to Mick Devereux and Massimiliano Pisani for detailed advice. We also thank Massimiliano Pisani for a very helpful discussion. Thanks for useful comments are also due to Gian Maria Milesi-Ferretti, Andrea Pescatori, Livio Stracca, Gert Peersman and Benoît Mojon, and to workshop participants at the European Commission and Ghent University, and at the CEF and DYNARE annual meetings. The views expressed in this paper are those of the authors and should not be attributed to the European Commission.
} 


\section{Introduction}

Since the early 2000s, the world economy has experienced major changes. Emerging economies grew rapidly, and their share in world output increased steadily. Both the US and the Euro Area (EA) experienced a boom-bust cycle. These developments have been accompanied by substantial trade balance adjustments. In the first half of the 2000s, the US trade balance deteriorated markedly, reaching about $-6 \%$ of GDP in $2005-7$, while the EA trade balance fluctuated around zero. After the Global Financial Crisis (2007-8), the EA and US trade balances both rose noticeably: the US trade deficit fell markedly, while the EA has been running steadily increasing trade balance surpluses.

This raises a number of questions: Has the EA/US boom-bust cycle been a major driver of global imbalances, or has the growth divergence between the rest of the world (RoW) and the EA/US shaped trade balances more strongly? A possible explanation for the widening pre-crisis US trade deficit is also provided by the saving glut hypothesis (Bernanke (2005)) which highlights the fact that rapid growth in the RoW has been associated with high RoW saving rates (perhaps due to heightened risk aversion as a consequence of the Asian financial crisis of the late 1990s). Thus high saving in the RoW may have outweighed the effect of high RoW productivity growth on the RoW external balance. A further factor (e.g., stressed by McKibbin and Stoeckel (2018)) that might help explain the trade balance facts, are the spectacular commodity price fluctuations during the last two decades: commodity prices rose sharply before the Global Financial Crisis, and collapsed afterwards. This might have contributed to the pre-crisis worsening of the US trade balance, and the EA and US post-crisis trade balance reversal. Note, however, that this factor is only partly independent from the other mechanisms mentioned above, since commodity prices may themselves be affected by the global business cycle.

To quantitatively evaluate the role of these mechanisms and forces, we develop a rich three-region New Keynesian DSGE (Dynamic Stochastic General Equilibrium) model of the 
world economy that includes a commodity sector. We estimate that model (with Bayesian Methods), using 1999q1-2017q2 data for the EA, US and an aggregate of rest of the world (RoW) countries. The use of a rich estimated model allows us to identify periods dominated by specific shocks. In the model, commodity prices endogenously respond to global macroeconomic conditions. However, commodity prices are also driven by commodity-specific supply and demand shocks that may, e.g., reflect the discovery of new oil fields, or changes in the commodity intensity of the manufacturing sector.

This paper argues that there is no mono-causal explanation for the dynamics of global real activity and of external imbalances. According to our estimates, the EA and US pre-crisis booms were mainly driven by positive domestic aggregate demand shocks. Our findings suggest that those shocks contributed to the widening pre-crisis trade deficit in the US, and also had a negative influence on the EA trade balance. The RoW growth divergence, which accelerated in the 2000s, was mainly driven by strong positive RoW aggregate supply (productivity) shocks; those RoW shocks only had a muted effect on EA and US trade balances. However, before the crisis, adverse aggregate demand shocks in RoW, driven by a rise in private saving rates, had a noticeable negative influence on EA and US trade balances. Our findings are thus consistent with a pre-crisis 'saving glut' effect (Bernanke (2005)) for both US and EA trade balances. We also find that positive commodity-specific demand shocks during the pre-crisis boom had a marked negative effect on EA and US trade balances.

As pointed out above, EA and US trade balances improved strongly after the Global Financial Crisis. This is often viewed as reflecting weak domestic aggregate demand. This paper provides a nuanced assessment of that view. In particular, we argue that commodity shocks played an important role for the post-crisis EA and US trade balance reversal. In the US, where the post-crisis slump and the contraction of aggregate demand was more short-lived than in the EA (see analysis in Kollmann et al (2016)), a major expansion of domestic commodity 
production and a fall in demand for imported commodities stabilized the trade deficit at a lower level, after the financial crisis. Similarly in the EA, negative shocks to commodity import demand contributed markedly to the post-crisis trade balance improvement. However, the post-crisis weakness of EA aggregate demand, and the depreciation of the Euro, also played a significant part in the EA trade balance reversal. Positive RoW aggregate demand shocks during the postcrisis period too contributed to the US and EA trade balance improvements. The broader lesson of this paper is thus that Emerging Markets (RoW) and commodity shocks are key drivers of advanced countries' trade balances and terms of trade.

The trade balance developments discussed in this paper have some parallels in the external adjustments triggered by the oil shocks of the 1970s; those shocks triggered a sharp rise in the trade balances of oil exporters, and a trade balance deterioration of the groups of advanced and (especially) non-fuel developing countries (Obstfeld and Rogoff (1996)). An important difference between the global macroeconomic environment of the 2000s and that of the 1970s, is that the 2000s saw massive growth in Emerging Markets, which suggests that the commodity price hikes of the 2000s might have been driven more by expanding demand for commodities, and less by adverse commodity supply shocks (OPEC) than the price hikes of the 1970s.

Quantitative analyses of oil and commodity price fluctuations mostly rely on reducedform statistical models, such as vector auto regressions (see, e.g., Kilian (2009), Kilian et al. (2009), Peersman and Van Robays (2009), ECB (2010), Caldara et al. (2017)), or on semistructural models (e.g., Dieppe et al. (2018)). With few exceptions, structural (DSGE) open economy models abstract from international trade in commodities. Existing DSGE models with commodity trade often assume a small open economy that faces exogenous commodity prices (e.g., Miura (2017)). By contrast, the paper here develops (and estimates) a multi-country DSGE model with endogenous commodity prices. The paper here is closest to Forni, Gerali, Notarpietro and Pisani (2015), who estimate a $t w o$-country DSGE model of the EA and the non-EA rest-of- 
the-world, using data for 1995-2012. ${ }^{1}$ Our model differs from that work in that we use a rich three-region model (EA, US, RoW) that allows us to analyze the noticeable differences between the dynamics of the EA and US external accounts. Our paper focuses on the interaction between the three regions, and we use a sample period that includes the post-2014 commodity price collapse. ${ }^{2}$ We document the key role of the expansion of US commodity production during the 2010s for the improvement in the US trade balance, during that period.

\section{EA, US and RoW macroeconomic conditions and external adjustment, 1999-2017}

This paper studies macroeconomic developments and linkages in the EA, US and an aggregate of the rest of the world (RoW). ${ }^{3}$ Figures 1-3 show time series for EA, US and RoW GDP and trade flows, since 1999. Fig.1a documents that real GDP growth has been markedly higher in RoW than in the EA and the US. The mean real GDP growth rates of the three regions in 1999-2016 were $1.3 \%$ (EA), $1.9 \%$ (US) and 3.6\% (RoW) per annum, respectively. As a result of this growth differential, the share of RoW GDP in total world GDP has increased steadily, from close to 40\% (1999) to more than 50\% (2016); see Fig. 1b. During the Great Recession (2008-9), GDP contracted in all three regions, but the contraction was milder in RoW than in the EA and US. In 2009-11, RoW growth rebounded to pre-crisis growth rates, and then declined somewhat. EA and US GDP growth too rebounded in 2009-11, but remained below pre-crisis growth rates. After the eruption of the Southern European sovereign debt crisis (2011), the EA experienced a recession (2012-13).

\footnotetext{
${ }^{1}$ Simpler multi-country DSGE simulation models of the role of energy for international adjustment have been developed by Sachs (1981), McKibbin and Sachs (1991), Backus and Crucini (2000) and Gars and Olovsson (2018) and Bornstein al. (2018).

${ }^{2}$ Forni et al. (2015) analyze the effects of oil shocks; by contrast, the paper here considers shocks to a broader bundle of commodities.

${ }^{3}$ RoW includes the 58 major developed and emerging economies other than the US and the EA member countries (see Data Appendix). The US, EA and RoW together account for more than 95\% of world GDP, in 1999-2016 (as reported by the IMF World Economic Outlook database).
} 
These divergent GDP trends and uncoupled cycles were accompanied by dramatic fluctuations in commodity prices, and by major shifts in the three regions' trade balances. The prices of a wide range of commodities rose sharply during the early 2000s, until the Global Financial Crisis. This is documented in Fig. 2a, where oil and coal prices as well as two global commodity price indices (in US dollars) are plotted. Note, e.g., that the oil price was multiplied by a factor greater than 5 between 1999 and 2008. Commodity prices contracted sharply during the financial crisis, but rebounded strongly after the crisis; commodity prices then fell again sharply (by more than 50\%) after 2011. To put these developments into a long-run perspective, Fig. 2b plots an index of real prices (deflated by the US CPI) of 40 commodities for the period 1900-2015, constructed by Jacks $(2013,2016)$. The magnitude of the recent commodity price boom-bust cycle is only comparable to the 1973-86 commodity boom-bust cycle; it dwarfs all other commodity cycles since 1900 .

EA net exports of goods (merchandise) fluctuated around zero before the crisis, and then rose steadily, reaching about $2.5 \%$ of EA GDP in 2016 (see Fig. 3b). Note that all data on trade flows used in this paper pertain to goods trade, as there are no time series for bilateral services trade, between the three regions (EA, US, RoW). ${ }^{4}$ By contrast to the EA, the US has been running a sizable trade deficit (goods) during the whole sample period (in fact, since the mid1980s). The US trade deficit peaked at about 6\% of GDP in 2005-07 (see Fig. 3c). The trade deficit has fallen after the financial crisis, to about 4\% of US GDP in 2017.

To understand whether/how these trade balance reversals might be linked to the commodity boom-bust cycle and the decoupled regional growth trends, we also plot EA and US net exports that are disaggregated by trade partner (regions), and by product (all net exports series are normalized by GDP); see Fig.3. Specifically, we disaggregate trade flows (goods) into:

\footnotetext{
${ }^{4}$ The EA and (especially) the US are running a net surplus for trade in services. However, the services trade surplus is smaller than the goods trade balance, and much more stable. The goods trade balance is thus highly positively correlated with the total (goods and services) trade balance.
} 
(i) 'industrial supplies and materials', (henceforth referred to as 'industrial supplies'), a broad basket of commodities comprising petroleum, mineral products and other raw materials; (ii) an aggregate of all other products, henceforth referred to as 'manufactures'.

The disaggregation of net exports by trade partners shows that the EA has been running a small and relatively stable trade balance surplus (ranging between about $0.5 \%$ and $1 \%$ of EA GDP) against the US, since 1999. Thus, trade with RoW drives the major swings in EA and US total net exports (see Figs. 3b and 3d). Trade with RoW also accounts for the lion share of EA and US gross trade flows. Manufactures account for more than $70 \%$ of EA bilateral gross trade with RoW, and for about $60 \%$ of bilateral US-RoW trade. ${ }^{6}$

The EA had a trade balance surplus for manufactures, and a trade deficit for industrial supplies, in 1999-2016 (see Fig. 3a). EA net exports of manufactures increased steadily until 2013, and then declined somewhat. EA net imports of industrial supplies rose before the crisis, fell somewhat during the crisis, then rose again (2010-11), and fell substantially thereafter. EA net imports of industrial supplies thus track closely the commodity price cycle (see above). The overall EA trade balance (across all products and trade partners) comoves closely with the EA's industrial supplies trade balance--the overall trade balance and the industrial supplies trade balance both improved markedly after 2012 .

The US has been running a persistent trade deficit, for manufactures and for industrial supplies. The dynamics of US net imports of industrial supplies too tracks the evolution of commodity prices. Net imports of industrial supplies have fallen more in the US than in the EA, after the financial crisis. Note that the US is a major producer and exporter of oil and other

\footnotetext{
${ }^{5}$ Bilateral trade flows for US-EA and US-RoW are from the BEA International Trade database; EA-RoW trade flows are from the Eurostat COMEXT database. The sum of COMEXT product categories 'raw materials' and 'mineral fuels and related products' closely matches the 'industrial supplies' product category in the BEA database. For simplicity, we refer to the sum of COMEXT 'raw materials' and 'mineral fuels and related products' as 'industrial supplies'. Importantly, EA exports and imports exclude intra-EA trade. EA and US trade flows to/from RoW represent flows to/from all countries other than the US and the EA.

${ }^{6}$ For brevity, Fig. 3 only shows EA and US net exports broken down by trade partner, and net exports disaggregated by product. A finer breakdown of (gross and net) trade flows by products and partner country is available on request.
} 
commodities, while the EA is a negligible producer/exporter of commodities. US crude oil production doubled between 2010 and 2015, driven by the expansion of oil shale extraction (Baffes et al. (2015)). This may have contributed to the sharper fall in US net commodity imports. Interestingly, US net imports of manufactures have followed an opposite trend (than US net commodity imports) and increased noticeably, after the crisis.

This overview of the historical data suggests that commodity shocks may have contributed to the post-crisis reversal of EA and US trade balances. Below, we use an estimated DSGE model to quantify the contribution of the commodity cycle to EA and US external balances, and we disentangle the influence of commodity-specific shocks from other drivers, such as aggregate demand and supply shocks.

\section{Model description}

We develop a model of a three-region world consisting of the EA, US and RoW. The three regions are linked via trade in goods and a financial asset. The EA and US blocks of the model are fairly rich; both blocks have the same structure (but model parameters are allowed to differ across these two regions). The RoW block of the model is simpler (fewer shocks). In all three regions, economic decisions are made by forward-looking households and firms; each region exhibits nominal and real rigidities, and is buffeted by a range of supply and demand shocks, as in standard New Keynesian DSGE models. A key difference between the regions is that the model postulates that only RoW produces commodities. Thus, in the model, all commodities used by the EA and US are imported from RoW.

The EA and US model blocks assume two (representative) infinitely-lived households, firms and a government. EA and US households provide labor services to domestic firms. One of the two households in each region has access to financial markets, and she owns her region's production capital and firms. The other household has no access to financial markets, does not 
own assets, and each period consumes her disposable wage and transfer income. We refer to these two agents as 'Ricardian' and 'hand-to-mouth' households, respectively.

In each region, a final good is produced by perfectly competitive firms that use local intermediate goods and imported commodities and manufactured goods as inputs. Intermediates are produced by monopolistically competitive firms using local labor and capital. Wage rates are set by monopolistic trade unions. Nominal intermediate good prices and nominal wages are sticky. Governments purchase the local final good, make lump-sum transfers to local households, levy labor and consumption taxes and issue domestic debt. All exogenous random variables follow independent autoregressive processes.

We next present the key aspects of the EA model block. As mentioned above, the US block has a symmetric structure. The RoW block is described in Section 3.5. ${ }^{7}$

\subsection{EA households}

A household's welfare depends on consumption and hours worked. EA household $i=r, h$ ( $r$ : Ricardian, $h$ : hand-to-mouth) has the period utility function

$$
U_{t}^{i} \equiv \frac{1}{1-\theta}\left(C_{t}^{i}-\eta^{C} C_{t-1}^{i}\right)^{1-\theta}-s_{t}^{N} \cdot\left(C_{t}^{i}\right)^{1-\theta} \frac{1}{1+\theta^{N}}\left(N_{t}^{i}-\eta^{N} N_{t-1}^{i}\right)^{1+\theta^{N}}
$$

with $0<\theta, \theta^{N}, s_{t}^{N}$ and $0<\eta^{C}, \eta^{N}<1 . C_{t}^{i}$ and $N_{t}^{i}$ are consumption and the labor hours of household $i$ in period $t$, respectively. We assume (external) habit formation for consumption and labor hours. ${ }^{8} s_{t}^{N}$ is an exogenous shock to the disutility of labor. Household behavior at date $t$ seeks to maximize expected life-time utility at that date, $V_{t}^{i}$, defined by $V_{t}^{i}=U_{t}^{i}+E_{t} \beta_{t, t+1} V_{t+1}^{i}$, where $0<\beta_{t, t+1}<1$ is a subjective discount factor that fluctuates exogenously.

\footnotetext{
${ }^{7}$ Here, we only present the main model features. A mode detailed presentation is available in a Not-for-Publication Appendix. The EA and US blocks build on, but are considerably different than the EU Commission's QUEST model of the EU economy; see Ratto et al. (2009); in't Veld et al. (2015), Kollmann et al. (2015, 2016).

${ }^{8}$ To allow for balanced growth, the disutility of labor features the multiplicative term $\left(C_{t}^{h}\right)^{1-\theta}$; this term is treated as exogenous by the household.
} 
The EA Ricardian household owns all domestic firms, and holds domestic government bonds (denominated in local currency and not traded internationally) and internationally traded bonds. Her period $t$ budget constraint is:

$$
\left(1+\tau^{C}\right) P_{t} C_{t}^{r}+B_{t+1}^{r}=\left(1-\tau^{N}\right) W_{t} N_{t}^{r}+B_{t}^{r}\left(1+i_{t}^{r}\right)+d i v_{t}+T_{t}^{r},
$$

where $P_{t}, W_{t}, d i v_{t}$ and $T_{t}^{r}$ are the consumption (final good) price, the nominal wage rate, dividends generated by domestic firms, and government transfers received by the Ricardian household. $B_{t+1}^{r}$ denotes the Ricardian household's total bond holdings at the end of period $t$, and $i_{t}^{r}$ is the nominal return on the household's bond portfolio between periods $t-1$ and $t . \tau^{C}$ and $\tau^{N}$ are (constant) consumption and labor tax rates, respectively.

The hand-to-mouth household does not trade in asset markets and simply consumes her disposable wage and transfer income. Her budget constraint is: $\left(1+\tau^{C}\right) P_{t} C_{t}^{h}=\left(1-\tau^{N}\right) W_{t} N_{t}^{h}+T_{t}^{h}$.

\subsection{EA technology and firms}

EA production is a multi-stage process. In the first stage, monopolistically competitive EA firms use domestic capital and labor to produce non-tradable differentiated intermediate goods. Perfectly competitive EA firms then combine domestic intermediates, imported commodities and imported manufactured goods to produce a final good that is used for domestic private and government consumption, investment and exports.

\subsubsection{EA intermediate goods sector}

In the EA, there is a continuum of intermediate goods indexed by $j \in[0,1]$. Each good is produced by a single firm. All EA intermediate good firms face identical decision problems. Firm $j$ has technology $y_{t}^{j}=\Theta_{t}\left(N_{t}^{j}\right)^{\alpha}\left(c u_{t}^{j} K_{t}^{j}\right)^{1-\alpha}$, where $y_{t}^{j}, N_{t}^{j}, K_{t}^{j}, c u_{t}^{j}$ are the firm's output, labor input, capital stock and capacity utilization, respectively. Total factor productivity (TFP) $\Theta_{t}>0$ is 
exogenous and common to all EA intermediate good producers. Log TFP is the sum of a stationary autoregressive process and of a unit root process whose first difference is highly serially correlated.

The law of motion of firm $j$ 's capital stock is $K_{t+1}^{j}=K_{t}^{j}(1-\delta)+I_{t}^{j}$, with $0<\delta<1 ; \quad I_{t}^{j}$ is gross investment. The period $t$ dividend of intermediate good firm $j$ is $d i v_{t}^{j}=p_{t}^{j} y_{t}^{j}-W_{t} N_{t}^{j}-P_{t}^{K} I_{t}^{j}-P_{t} \kappa_{t}^{j}$, where $p_{t}^{j}$ and $P_{t}^{K}$ are the price charged by the firm and the price of production capital, respectively. At $t$, each intermediate good firm faces a downward sloping demand curve for her output, with exogenous price elasticity $\varepsilon_{t}>1$ that equals the substitution elasticity between different intermediate good varieties (see below). The firm bears a real cost $\kappa_{t}^{j} \equiv \frac{1}{2} \gamma\left(p_{t}^{j}-(1+\pi) p_{t-1}^{j}\right)^{2} / p_{t}^{j}$ of changing her price, where $\pi$ is the steady state inflation rate.

The quadratic price adjustment cost implies that the inflation rate of local intermediates $\pi_{t}=\ln \left(p_{t}^{j} / p_{t-1}^{j}\right) \quad$ obeys an expectational Phillips curve, up to a linear approximation: $\pi_{t}-\pi=\beta E_{t}\left(\pi_{t+1}-\pi\right)+\vartheta^{j}\left(M C_{t} / p_{t}^{j}-\frac{\varepsilon-1}{\varepsilon}\right)$. Here $M C_{t}^{j}$ is the marginal cost of intermediate good firms and $(\varepsilon-1) / \varepsilon$ is the inverse of the steady state mark-up factor. $\beta$ is the steady state subjective discount factor of intermediate good firms, and $\vartheta^{j}>0$ is a coefficient that depends on the cost of changing prices.

\subsubsection{EA final good sector}

The EA final good $\left(O_{t}\right)$ is produced from domestic and imported inputs, using the technology $O_{t}=\left(\left(S_{t}^{d}\right)^{1 / \mathcal{V}^{\rho}}\left(D_{t}\right)^{\left(\mathcal{V}^{\rho}-1\right) / \mathcal{V}^{\rho}}+\left(1-S_{t}^{d}\right)^{1 / \mathcal{V}^{\rho}}\left(M_{t}\right)^{\left(\mathcal{I}^{\mathcal{\rho}}-1\right) / \mathcal{V}^{\rho}}\right)^{\mathcal{V}^{\mathcal{\rho}} /\left(\mathcal{V}^{\mathcal{\rho}}-1\right)}$, with home bias parameter $0.5<s_{t}^{d}<1$ and substitution elasticity $v^{\circ}>0 . M_{t}$ is a composite of the manufactured goods imported by EA (from US and

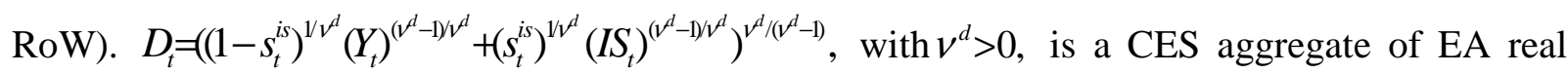


domestic value added, $Y_{t}$, and industrial supplies $I S_{t}$ (energy and non-energy commodities) imported from RoW. $Y_{t} \equiv\left\{\int_{0}^{1}\left(y_{t}^{j}\right)^{\left(\varepsilon_{t}-1\right) / \varepsilon_{t}} d j\right\}^{\varepsilon_{t}\left(\varepsilon_{t}-1\right)}$ is an aggregate of the local intermediates (see 3.2.1). The CES-weight attached to commodities, $0<s_{t}^{i s}<1$, is an exogenous random variable that captures (region-specific) changes in the commodity intensity of final good production. We refer to $s_{t}^{i s}$ as a 'commodity-specific demand shock', because $s_{t}^{i s}$ has a direct effect on commodity demand. Note that EA commodity demand obeys $I S_{t}=\left(s_{t}^{i s} /\left(1-s_{t}^{i s}\right)\right) \times Y_{t} \times\left(P_{t}^{i s} / P_{t}^{y}\right)^{-v^{d}}$. A fall in $s_{t}^{i s}$ (reduction in commodity intensity) lowers EA commodity demand, for given values of $Y_{t}$ and of the real commodity price $P_{t}^{i s} / P_{t}^{y}$ (where $P_{t}^{i s}$ and $P_{t}^{y}$ are the prices of $I S_{t}$ and $Y_{t}$, respectively).

The price (=marginal cost) of the EA final good is $P_{t}=\left(s_{t}^{d}\left(P_{t}^{d}\right)^{1-v^{o}}+\left(1-s_{t}^{d}\right)\left(P_{t}^{m}\right)^{1-v^{o}}\right)^{1 /\left(1-v^{o}\right)}$, where $P_{t}^{d}=\left(\left(1-s_{t}^{i s}\right)\left(P_{t}^{y}\right)^{1-v^{d}}+s_{t}^{i s}\left(P_{t}^{i s}\right)^{1-v^{d}}\right)^{1 /\left(1-v^{d}\right)}$ while $P_{t}^{m}$ is the import price index.

The EA final good $O_{t}$ is used for domestic private and government consumption, for investment and for exports.

\subsubsection{EA export sector}

There is a monopolistically competitive EA export sector. Firm in that sector purchase and 'differentiate' the EA final good, and then sell it to foreign final good firms. Like intermediate good producers (see above), exporters face price adjustment costs. We assume that a fraction of EA exporters sets prices in Euro (producer currency price setting, PCP). The remaining exporters set prices in destination currency (pricing to market, PTM); see Betts and Devereux (2000). We estimate the share of each region's export firms that use PTM. 


\subsubsection{EA capital goods sector}

New production capital is generated using the domestic final good. Let $\Xi_{t} \xi\left(I_{t}\right)$ be the amount of EA final good needed to produce $I_{t}$ units of EA capital. $\xi$ is an increasing, strictly convex function, while $\Xi_{t}$ is an exogenous shock. The price of production capital is $P_{t}^{K}=\Xi_{t} \xi^{\prime}\left(I_{t}\right) P_{t}$.

\subsection{Wage setting in the $E A$}

We assume a monopolistic EA trade union that 'differentiates' homogenous EA labor hours provided by the two domestic households into imperfectly substitutable labor services; the union then offers those services to local intermediate good firms; the labor input $N_{t}$ in those firms' production functions is a CES aggregate of these differentiated labor services. The union sets wage rates at a mark-up over the marginal rate of substitution between leisure and consumption. The wage mark-up is inversely related to the degree of substitution between labor varieties in intermediate good production.

\subsection{EA monetary and fiscal policy}

The EA monetary policy (nominal) interest rate $i_{t+1}$ is set at date $t$ by the EA central bank according to the interest rate feedback rule

$$
i_{t+1}=\left(1-\rho^{i}\right) \bar{i}+\rho^{i} i_{t}+\left(1-\rho^{i}\right)\left[\eta^{\pi}\left\{\frac{1}{4} \ln \left(P_{t} / P_{t-4}\right)-\pi\right\}+\eta^{Y} Y_{t}^{g a p}\right]+\varepsilon_{t}^{i},
$$

where $Y_{t}^{\text {gap }}$ is the EA output gap, i.e. the (relative) deviation of actual GDP from potential GDP; ${ }^{9}$ $\varepsilon_{t}^{i}$ is a white noise disturbance. EA real government consumption, $G_{t}$, is set according to the rule $c_{t}^{G}-c^{G}=\rho^{G}\left(c_{t-1}^{G}-c^{G}\right)+\varepsilon_{t}^{G}$, where $c_{t}^{G} \equiv P_{t} G_{t} /\left(P_{t}^{y} Y_{t}\right)$ is government consumption normalized by

\footnotetext{
${ }^{9}$ Date $t$ potential GDP is defined as GDP that would obtain under full utilization of the date $t$ capital stock and steady state hours worked, if TFP equaled its trend (unit root) component at $t$.
} 
domestic value added. EA government transfers to households follow a feedback rule that links transfers to the government budget deficit and to government debt.

\subsection{The RoW block}

As mentioned above, the RoW model block has a simplified structure. Specifically, the RoW block consists of a budget constraint for the representative (Ricardian) household, demand functions for domestic and imported inputs (derived from a CES final good aggregator), a New Keynesian Phillips curve, and a Taylor rule for monetary policy. The RoW production structure for manufactures is analogous to that of the EA and US, except that we assume that RoW does not use physical capital, and so there is no physical investment in RoW. ${ }^{10}$

In RoW, a competitive sector supplies two distinct commodities (indexed using superscript ' $c$ '), namely energy and non-energy materials, to domestic and foreign final good firms. ${ }^{11}$ Commodity prices are flexible. The commodity supply price denominated in RoW currency, $P_{R o W, t}^{c}$, normalized by the RoW GDP deflator, $P_{R o W, t}^{y}$, is an increasing function of RoW commodity production, $I S_{t}^{c}: \ln \left(P_{R o W, t}^{c} / P_{R o W, t}^{y}\right)=\eta \times \ln \left(I S_{t}^{c}\right)-\varepsilon_{t}^{c}$, where $\varepsilon_{t}^{c}$ is a disturbance that captures exogenous commodity supply shocks (such as the discovery of new raw material deposits). The parameter $\eta^{I S}$ is the inverse of the price elasticity of commodity supply. ${ }^{12}$

EA, US and RoW demand for commodities is determined by final good producers in these regions. US and RoW demand functions for commodities are analogous to the EA demand

\footnotetext{
${ }^{10}$ Our data set includes GDP data for RoW, but RoW investment (and consumption) data are not available. The RoW model block assumes domestic frictions (habit formation) and external frictions (foreign bond holding costs) that might give the model sufficient flexibility to capture the empirical dynamics of RoW absorption, despite the fact that the theoretical setup abstracts from RoW physical investment.

${ }^{11}$ Previous open economy DSGE models with oil (see Sect. 1) assume that oil is non-storable as, empirically, oil storage is costly and very limited (e.g., Bornstein et al. (2018)). We follow that assumption. For simplicity, we postulate that non-energy commodities too are non-storable.

${ }^{12}$ We experimented with variants of the commodity supply schedule that also included lagged quantities (IS) on the right-hand side, to allow the short-run price elasticity to differ from the long-run elasticity. The coefficients of lagged quantities were insignificant, and short- and long-run supply elasticities were not significantly different. Also, the implied model dynamics was unaffected. In what follows, we thus use the simple static commodity supply equation shown above.
} 
function shown in Sect. 3.2.2. However, we assume that the commodity intensity of RoW final good production is constant, i.e. there are no stochastic RoW commodity-specific demand shocks. This assumption is made because we lack data on RoW commodity production and on RoW commodity demand. Therefore, a RoW commodity-specific demand shock is not identified in our empirical model. By contrast, identification of the EA and US commodity-specific demand shocks is possible, as the model estimation uses volume and price data on commodity imports by EA and US from RoW.

Empirically, the EA and US commodity import price indices differ (but are highly positively correlated). To account for those differences (which may reflect different commodity import mixes), we assume that competitive RoW export firms bundle energy and non-energy commodities into destination-specific CES commodity aggregates. The 'commodity supply shocks' discussed in the historical shock decompositions below (see Sect. 5.3) include the shocks to RoW commodity supply schedules $\left(\varepsilon_{t}^{c}\right)$, as well as disturbances to the destination-specific RoW commodity export bundles.

In RoW, there are also shocks to labor productivity, the subjective discount rate, the relative preference for domestic versus imported manufactured goods, and to monetary policy.

\subsection{International financial markets}

The only internationally traded asset (held by Ricardian households) is a one-period bond denominated in RoW currency. ${ }^{13}$ Ricardian households face a small quadratic cost associated with their net foreign bond holdings (normalized by nominal GDP) from a target value (that cost is rebated to the households in a lump sum fashion). This implies that foreign vs. domestic interest rate spreads depend on foreign bond holdings (see Kollmann $(2002,2004)$ ). E.g., the

\footnotetext{
${ }^{13}$ As discussed below, we solve the model using a linear approximation around the steady state. Steady state net foreign assets of the three regions are set at zero. Up to a linear approximation around the steady state, the valuation effects of exchange rate changes are thus zero, and the currency denomination of the internationally traded bond is irrelevant.
} 
first-order conditions of the EA Ricardian household for domestic and international bonds yield this modified EA uncovered interest parity (UIP) condition, up to a log-linear approximation: $i_{R O W, t+1}+\mathrm{E}_{t} \ln \left(e_{E A, t+1}^{R O W} / e_{E A, t}^{R O W}\right)=i_{t+1}+\alpha^{b} b_{t+1}+\varepsilon_{t}^{b}, \alpha^{b}>0$, where $i_{R O W, t+1}$ and $i_{t+1}$ are RoW and domestic interest rates at date $t, e_{E A, t}^{R O W}$ is the EA-RoW exchange rate (Euro per unit of RoW currency), and $b_{t+1}$ is the EA's foreign bond position (normalized by GDP). $\varepsilon_{t}^{b}$ is an exogenous shock to the cost of holding foreign bonds, referred to as a 'bond premium' shock in the historical shock decompositions discussed below (see Sect. 5.3).

\subsection{Exogenous shocks}

The estimated model assumes 66 exogenous shocks. Other recent estimated DSGE models likewise assume many shocks (e.g., Kollmann et al. $(2015,2016))$, as it appears that many shocks are needed to capture the key dynamic properties of macroeconomic variables. The large number of shocks is also dictated by the fact that we use a large number of observables (time series for 60 variables) for estimation, to shed light on different potential causes of economic fluctuations and external adjustment in the three regions. Note that the number of shocks has to be at least as large as the number of observables to avoid stochastic singularity of the model.

\section{Model solution and econometric approach}

We compute an approximate model solution by linearizing the model around its deterministic steady state. Following the recent literature that estimates DSGE models, we calibrate a subset of parameters to match long-run data properties and we estimate the remaining parameters with Bayesian methods. The observables used in estimation are listed in the Data Appendix. ${ }^{14}$

\footnotetext{
${ }^{14}$ As the theoretical model abstracts from EA and US commodity production and exports, we use net commodity imports as observables for EA and US commodity demand. We follow the empirical DSGE literature (e.g., Kollmann et al. $(2015,2016)$ ), and select observables such that each shock has at least one associated observable that is strongly impacted by the shock. All shocks have a sufficiently distinct impact on observables so that shock identification is possible. The observables are not demeaned or detrended prior to estimation. The model is estimated
} 
One period in the model is taken to represent one quarter in calendar time. The model is thus estimated using quarterly data. The estimation period is 1999q1-2017q2.

We calibrate the model such that steady state ratios of main spending aggregates to GDP match average historical ratios for the EA and the US. The steady state shares of EA and US GDP in world GDP are set at $17 \%$ and $25 \%$, respectively. The steady state trade share $\left(0.5^{*}\right.$ (exports+imports)/GDP) is set at $18 \%$ in the EA and $13 \%$ in the US. ${ }^{15}$ Steady state net foreign asset positions of the three regions are set at zero.

The EA (US) steady state ratios of private consumption and investment to GDP are set to $56 \%(67 \%)$ and $19 \%(17 \%)$, respectively. We set the steady state government debt/annual GDP ratio at $80 \%$ of GDP in the EA and $85 \%$ in the US. The EA and US steady state real GDP growth rate and inflation are set at $0.35 \%$ and $0.4 \%$ per quarter, respectively. Finally, the quarterly depreciation rate of capital is $1.4 \%$ in the EA and $1.7 \%$ in the US; we set the effective rate of time preferences to $0.25 \%$ per quarter.

\section{Estimation results ${ }^{16}$}

\subsection{Posterior parameter estimates}

The posterior estimates of key model parameters are reported in Table 1. (Estimates of other parameters can be found in the Not-for-Publication Appendix.) The steady state consumption share of the Ricardian household is estimated at 0.72 in the EA and 0.84 in the US. Estimated consumption habit persistence is high in the EA (0.86) and the US (0.71), which indicates a sluggish adjustment of consumption to income shocks. The estimated risk aversion coefficient is

on first differences of logged real GDP, real demand components, and price indices, and on nominal ratios of aggregate demand components, trade flows and trade balances to GDP. We use the DYNARE software (Adjemian et al. (2011)) to solve the linearized model and to perform the estimation.

${ }^{15}$ We calibrate the substitution elasticity between energy and non-energy commodities at 0.5 . The model estimation uses quarterly data on aggregate commodity imports of the EA and the US from RoW. Quarterly commodity import series disaggregated into energy vs. and non-energy are not available. Thus, the substitution elasticity between energy and non-energy commodities is not well identified-which is why that elasticity is calibrated.

${ }^{16}$ The presentation of results below focuses on key parameter estimates, impulse responses and historical shock decomposition. Additional results can be found in the Not-for-Publication Appendix. 
1.74 in the EA and 1.68 in the US. The parameter estimates suggest a slightly lower labor supply elasticity in the US than in the EA. Price elasticities of aggregate imports are 1.20 for the EA and 1.22 for the US.

The estimated substitution elasticity (in final good production) between commodities and real domestic value added is 0.02 for the EA and 0.05 for the US (see row labelled 'Commodity demand elasticity' in Table 1). That substitution elasticity corresponds to the price elasticity of commodity demand. Our estimate of the price elasticity of RoW commodity supply is 0.55 . Our low estimates of the EA and US price elasticities of commodity demand are in line with the literature, but our estimate of the price elasticity of commodity supply is somewhat higher than elasticities reported in the literature. See, e.g., Arezki et al. (2015) who report estimated price elasticities of oil demand [supply] in the range of 0.02 [0.1].

The model estimates suggest substantial nominal price stickiness. Estimated price adjustment cost parameters are slightly higher in the US (24.7) than in the EA (22.2), whereas wage stickiness is higher in the EA (3.83) than in the US (3.39). The estimated shares of EA, US and RoW manufactured goods exporters that set prices in destination-country currency ('pricing to market', PTM) are $0.23,0.16$ and 0.53 , respectively. Thus, PTM is markedly more prevalent among RoW exporters.

Estimated monetary and fiscal policy parameters are similar across both regions. The estimated EA and US interest rate rules indicate a strong response of the policy rate to domestic inflation, and a weak response to domestic GDP.

The estimates also suggest that most exogenous variables are highly serially correlated. The standard deviation of innovations to subjective discount factors, price mark-ups, trade shares, commodity-specific demand and to commodity supply are sizable.

The model properties discussed in what follows are evaluated at the posterior mode of the model parameters. 


\subsection{Impulse responses}

This section discusses estimated dynamic effects of key shocks shown in Figs. 4a-4d. We concentrate on the impact of supply and demand shocks originating in the RoW. The effects of supply and demand shocks originating in the EA and the US on domestic GDP are qualitatively similar to those predicted by standard DSGE models (see Kollmann et al. (2016) for a detailed recent discussion), but in the setting here, those effects tend to be somewhat smaller because of the endogenous response of commodity prices. In all impulse response plots, the responses of RoW, EA and US variables are represented by continuous blue, dashed red and dash-dotted black lines, respectively.

\subsubsection{Effects of a persistent RoW TFP shock}

Our model estimates suggest that persistent RoW TFP shocks were the main drivers of historical RoW GDP fluctuations (see historical shock decomposition in Fig. 5b, discussed below). Fig. 4a shows dynamic responses to a persistent positive shock to the RoW TFP growth rate that permanently raises the level of RoW GDP by about $2 \%$ within 10 years. The persistent increase in the supply of RoW tradables triggers a deterioration of the RoW terms of trade for manufactured goods, and an immediate nominal and real depreciation of the RoW currency. At the same time, the expectation of a persistent rise in RoW TFP and GDP boosts RoW aggregate demand. This explains why RoW inflation increases.

Because of adjustment frictions (consumption habits, credit frictions, investment adjustment costs), the response of domestic and foreign absorption is nevertheless quite gradual. This explains why the effect on trade balances is relatively modest, despite stronger responses of 
gross trade flows. ${ }^{17}$ (All trade balance responses pertain to the nominal trade balance normalized by nominal GDP.) Initially, the Euro and Dollar appreciation dominates the response of EA and US trade balances, which fall on impact; however, these trade balances quickly rise because of higher RoW demand for EA and US export goods. US and EA export volumes stabilize rapidly at higher levels, while import volumes grow more gradually.

Higher growth in RoW TFP raises commodity prices. This effect is strong enough to induce a slight improvement of the overall RoW terms of trade. The rise in commodity prices offsets the positive export demand effect on EA and US GDP. EA and US GDP are barely affected by the positive shock to RoW TFP.

The role of the endogenous commodity price channel for international shock transmission is highlighted in Fig. 4d, where we compare dynamic responses to the RoW TFP shock across the baseline model (flexible commodity price) and a model variant in which the US dollar price of commodities does not respond to the shock. ${ }^{18}$ The responses of EA and US real GDP are more positive in the model variant with constant dollar commodity prices, but remain modest. ${ }^{19}$ In other terms, the endogenous commodity price response in our baseline model dampens the strength of the GDP spillover from RoW to the EA and the US.

\subsubsection{Effects of a RoW aggregate demand shock}

Aggregate demand shocks in RoW too were key drivers of historical RoW GDP growth, and these shocks also mattered significantly for historical EA and US trade balance fluctuations (see shock decompositions in Figs. 5e and 5f, discussed below). Fig. 4b shows dynamic responses to a

\footnotetext{
${ }^{17} \mathrm{By}$ contrast, in a textbook permanent income model without adjustment frictions, persistent TFP growth rate shocks trigger rapid and strong responses of aggregate demand and, thus, of trade balances (Obstfeld and Rogoff (1996)).

${ }^{18}$ In that model variant, the supply of commodities is assumed to be infinitely elastic, at the given dollar price (all remaining model parameters are unchanged). Considering a fixed dollar commodity price provides an interesting perspective on the role of commodity price dynamics, because of widespread dollar invoicing in global commodity markets.

${ }^{19}$ In the baseline model, the negative wealth effect of a rising commodity import bill translates into a negative response of EA consumption. When commodity prices (in dollars) do not change, EA and US consumption both increase (and investment falls less) and EA/US commodity demand rises much more.
} 
negative aggregate demand shock in RoW, namely a persistent rise in the subjective discount factor of RoW households (i.e. a positive saving shock). The shock reduces RoW GDP and RoW import demand, and it depreciates the RoW currency. EA and US GDP fall, and EA and US trade balances deteriorate. The adverse RoW aggregate demand shock markedly reduces commodity prices, which weakens the negative international GDP spillover effect, compared to a model variant with unresponsive dollar commodity prices. RoW aggregate demand shocks are thus potential contributors to the high empirical volatility of commodity prices.

\subsubsection{Effects of a RoW commodity supply shock}

The previous discussion shows that commodity prices respond to aggregate supply and demand shocks. In addition, commodity prices exhibit strong responses to commodity supply shocks and to commodity-specific demand shocks. The model estimates suggest that these shocks are highly persistent.

Fig.4c. presents dynamic responses to a permanent positive commodity supply shock (RoW). The shock triggers a permanent fall in commodity prices, and a strong nominal and real depreciation of the RoW currency. It permanently raises GDP and absorption in the three regions. The commodity supply shock triggers a strong rise in RoW gross export volumes, and a contraction in RoW gross import volumes. Due to the low price elasticity of commodity demand, a positive RoW commodity supply shock lowers the commodity export revenue received by RoW, in domestic GDP units. Thus, the commodity trade balances of the EA and US (in GDP units) improve. The sharp fall in commodity prices also explains why real consumption increases much less in RoW than in the EA and the US. The RoW commodity supply shock improves the EA and US terms of trade for manufactured goods, and it deteriorates the EA and US trade balances for manufactures. Thus, the responses of the manufactures' trade balance have an offsetting (stabilizing) effect on the overall trade balance. At the estimated model parameters, the 
response of the overall US trade balance is close to zero, while there is a noticeable improvement in the overall EA trade balance.

\subsection{Historical shock decompositions}

To quantify the role of different shocks as drivers of endogenous variables in the period 19992017, we plot the estimated contribution of these shocks to historical time series. Figs. 5a-5f show historical shock decompositions of year-on-year (yoy) growth rates of the commodity price (in Euro), and of RoW, EA and US GDP; also shown are historical shock decompositions of EA and US trade balance/GDP ratios. In each sub-plot, the continuous thick black line shows historical time series, from which sample averages have been subtracted. The vertical black bars show the contribution of different groups of exogenous shocks (see below) to the historical data, while stacked light bars show the contribution of the remaining shocks. Bars above the horizontal axis represent positive shock contributions, while bars below the horizontal axis show negative shock contributions.

Given the large number of shocks, we group together the contributions of related shocks. Specifically, 'TFP RoW', 'TFP EA' and 'TFP US' represent the contributions of permanent and transitory productivity shocks in RoW, the EA, and the US, respectively. 'Aggregate demand RoW', 'Aggregate demand EA' and 'Aggregate demand US' capture the effect of aggregate demand shocks (including household saving shocks, fiscal/monetary policy shocks and investment risk premium shocks). 'Bond premia' shocks represent the contribution of shocks to UIP conditions. 'Commodity supply' shocks represent shocks to RoW commodity supply. 'Commodity-specific demand' shocks represent the combined effect of EA and US commodityspecific demand shocks (i.e. shocks to the commodity intensity of EA and US final good production; see Sect. 3.2.2). ${ }^{20}$

\footnotetext{
${ }^{20}$ As mentioned in Sect. 3.5, the model assumes that there are no RoW commodity-specific demand shocks.
} 


\subsubsection{Commodity (industrial supplies) prices}

According to our estimates, historical commodity prices were mainly driven by EA and US commodity-specific demand shocks, and by commodity supply shocks (see Fig. 5a). Commodityspecific demand shocks were the major drivers of the pre-crisis commodity price boom, and of the price collapse during the financial crisis, while commodity supply shocks were key drivers of the post-crisis commodity price contraction.

Adverse aggregate demand shocks in the three regions made a smaller, but noticeable, contribution to the sharp commodity price contraction during the financial crisis. Aggregate demand shocks had only a minor role for commodity prices, before and after the crisis. Throughout the sample period, TFP shocks had a negligible effect on commodity prices.

To understand the central role of EA and US commodity-specific demand shocks for historical commodity prices, according to the estimated model, one should note that the fitted commodity-specific demand shocks account for fluctuations in commodity demand that are not explained by movement in EA and US GDP and in the real commodity price (see Sect. 3.2.2). Despite its richness, the model abstracts from some key real world drivers of EA and US commodity demand. Thus, fitted commodity-specific demand shocks may capture the effect of a range of empirical disturbances, besides pure shocks to the commodity intensity of EA and US final good production.

Recall, in particular, that the model abstracts from US (and EA) commodity production and exports. Yet, US crude oil production doubled between 2010 and 2015. Our estimated model largely attributes the post-crisis fall in US net commodity imports to negative US commodityspecific demand shocks. Those fitted shocks probably partly reflect the post-crisis expansion of US commodity production.

The commodity-specific demand shocks identified by the model may also capture changes in the sectoral composition of aggregate real activity that are not accounted for by our 
theoretical production structure. During recessions, highly commodity-intensive sectors (manufacturing) tend to reduce output much more strongly than less commodity-intensive sectors (services). The model does not capture that cyclical composition effect. This may help to understand why the model largely attributes the collapse in commodity prices during the Great Financial Crisis to negative commodity-specific demand shocks. ${ }^{21}$ However, it seems implausible that the post-crisis fall in commodity prices was mainly driven by adverse aggregate demand/supply shocks, as by 2013 GDP growth had resumed both in the US and the EA, after having recovered earlier in the RoW. This implies that 'commodity-specific' supply and demand factors are the most likely drivers of the post-crisis dynamics of commodity prices and commodity imports.

Empirically, EA and US commodity demand is procyclical, and much more volatile than GDP; the fitted commodity-specific demand shocks too are procyclical and highly volatile. ${ }^{22}$ In an attempt to capture effects of aggregate real activity on commodity demand that are potentially missing from the baseline model, we have experimented with a model variant that features a direct impact of aggregate activity on the EA and US commodity-specific demand shifters $\left(s_{t}^{i s}\right.$; see Sect. 3.2.2). Specifically, those demand shifters are assumed to be (increasing) functions of domestic capacity utilization, and of exogenous region-specific disturbances. ${ }^{23}$ The slope coefficients are set by regressing fitted EA and US commodity-specific demand shocks, from our

\footnotetext{
${ }^{21}$ Forni et al. (2015), who estimated a two-country (EA, RoW) DSGE model with oil, too find a non-negligible role of commodity-specific demand shocks for the oil price, but in their set-up aggregate demand shocks matter significantly for the oil price. Forni et al. (2015) do not use data on regional oil demand/imports. By contrast, our estimation uses data on EA and US commodity net imports from RoW, as well as data on the determinants of commodity demand (real GDP, relative commodity price), which allows a direct identification of commodityspecific demand shocks, in the context of our model.

${ }^{22}$ For the EA [US], the standard deviations (std.) of the quarterly growth rates of commodity net imports and GDP are $1.48 \%$ [18.74\%] and $0.61 \%$ [0.62], respectively, and the correlation between the two series is 0.58 [0.24]. The std. of growth rates of EA and US fitted commodity-specific demand shocks are $1.36 \%$ and $9.80 \%$, respectively. The correlation between fitted commodity-specific demand shocks and capacity utilization is 0.29 [0.61] for the EA [US]. ${ }^{23} s_{t}^{i s}=\alpha_{0}+\alpha_{1} c u_{t}+\xi_{t}, \alpha_{1}>0$, where $c u_{t}$ is capacity utilization, while $\xi_{t}$ is an exogenous shock. This model variant is inspired by Finn $(1995,2000)$ and Forni et al. (2015) who develop DSGE models in which oil demand is a direct function of capacity utilization.
} 
baseline model, on historical EA and US capacity utilization data. Note that this experiment is set up to maximize the influence of a highly cyclical variable (capacity utilization) on commodity demand. In this experiment, the exogenous shocks to the EA and US commodity-specific demand shifter still explain about half of the commodity price collapse during the Global Financial Crisis. Overall, during our sample period (1999-2017), the influence of exogenous commodity-specific demand shocks on commodity prices shrinks by about one third, while the impact of aggregate demand shocks rises slightly. However, most importantly, exogenous commodity supply shocks and exogenous commodity-specific demand shocks remain the main drivers of commodity prices, especially during the post-crisis period, and they continue to be significant drivers of the postcrisis trade balance reversal in the EA and US (see below)

\subsubsection{RoW GDP growth}

According to the estimated model, strong RoW GDP growth was mainly driven by persistent positive domestic TFP shocks (see Fig. 5b). The growth of RoW TFP and GDP was, however, interrupted in 2001 and 2008-9, i.e. by the recessions following the dot-com bubble and by the Global Financial Crisis. After 2010, we again detect sustained positive TFP contributions to RoW GDP growth. Domestic aggregate demand shocks too were influential drivers of RoW GDP fluctuations. The model identifies negative RoW aggregate demand shocks in the late 1990s and early 2000s that reflected increased RoW household saving rates (perhaps due to heightened risk aversion in the aftermath of the Asian debt crisis). RoW aggregate demand remained weak until the mid-2000s. A large negative RoW aggregate demand shock occurred during the Global Financial Crisis, which was followed by positive RoW aggregate demand shocks in 2010-11.

\subsubsection{EA and US GDP growth}

Fluctuations in EA and US GDP growth were largely driven by domestic aggregate demand shocks (in particular by household saving shocks and by investment shocks); see Figs. 5c and 5d. 
After the Global Financial Crisis, domestic aggregate demand and GDP rebounded more quickly in the US than in the EA, which experienced a recession in 2012-13. In both the US and the EA, monetary and fiscal policy provided some GDP stabilization (not shown in Figures). The contribution of domestic TFP shocks to historical GDP fluctuations has been much smaller in the EA and US than in RoW. Consistent with the weak international transmission effects discussed above, we find that EA and US GDP were hardly affected by RoW TFP shocks. However, RoW aggregate demand shocks had noticeable positive spillover effects on EA GDP.

\subsubsection{EA and US trade balances}

In the period before the financial crisis, the US trade balance declined markedly, while the EA trade balance was trendless and fluctuated around zero; after the crisis, the EA and US trade balances both rose strongly and persistently (see discussion in Sect. 2).

Our model estimates show that positive shocks to RoW saving and to US aggregate demand had a negative influence on the US trade balance, during the pre-crisis period (see Fig. 5f). Before the crisis, adverse RoW aggregate demand shocks and positive EA aggregate demand shocks also affected the EA trade balance negatively (Fig. 5e); however, we identify countervailing forces on the EA trade balance, in particular the depreciation of the Euro in the early 2000s. ${ }^{24}$ Note that our estimates are consistent with a RoW 'saving glut' effect (Bernanke (2005) on both US and EA trade balances.

In 2002-08, positive commodity-specific demand shocks had a significant negative influence on both the EA and US trade balance; however, these shocks were probably partly induced by the pre-crisis boom itself (strong cyclical responsiveness of net commodity imports).

\footnotetext{
${ }^{24}$ See the positive contribution of 'Bond premia' shocks to the EA trade balance in Fig. 5e. According to the estimated model, the Euro depreciation was largely driven by 'Bond premia' shocks, namely by EA UIP shocks that lowered demand for Euro bonds.
} 
Our estimation results suggest that commodity shocks played a central role for the post$\underline{\text { crisis }}$ EA and US trade balance reversals. In the US, large negative commodity-specific demand shocks (that likely in part reflect the expansion of US commodity production; see discussion above) had an especially strong and sustained positive influence on net exports, after the crisis. In the EA, too, negative commodity-specific demand shocks contributed markedly to the post-crisis trade balance increase (positive commodity supply shocks likewise contributed to the EA trade balance reversal).

However, the persistent post-crisis weakness of EA aggregate demand and the depreciation of the Euro also played a significant part in the rise of the EA trade balance. Strong RoW aggregate demand during the post-crisis period too contributed to the EA and US trade balance improvements. The more rapid and stronger post-crisis rebound of US domestic aggregate demand actually had a negative influence on the US trade balance.

\section{Conclusion}

This paper identifies key shocks that have driven economic fluctuations and external adjustment, in the Euro Area (EA), the US and the rest of the world (RoW), since 1999. Our empirical analysis is based on an estimated three region DSGE model of the world economy that includes a commodity sector. The sample period saw very large commodity price fluctuations. We find that RoW GDP growth was largely driven by persistent TFP shocks, while EA and US GDP fluctuations mainly reflected domestic aggregate demand shocks. The paper highlights the key contribution of commodity shocks for the dynamics of EA and US trade balances, particularly for the strong and persistent post-crisis EA and US trade balance improvements. Aggregate demand shocks originating in RoW too had a significant impact on EA and US trade balances. The broader lesson of this paper is thus that Emerging Markets (RoW) and commodity shocks are major drivers of advanced countries' trade balances and terms of trade. 


\section{References}

Adjemian, Stéphane, Houtan Bastani, Michel Juillard, Frédéric Karamé, Ferhat Mihoubi, George Perendia, Johannes Pfeifer, Marco Ratto and Sébastien Villemot, 2011. Dynare: Reference Manual, Version 4. Dynare Working Papers, 1, CEPREMAP.

Arezki, Rabah, Zoltan Jakab, Douglas Laxton, Akito Matsumoto, Armen Nurbekyan, Hou Wang, and Jiaxiong Yao, 2017. Oil Prices and the Global Economy. IMF Working Paper WP/17/15.

Backus, David and Mario Crucini, 2000. Oil Prices and the Terms of Trade. Journal of International Economics 50, 185-213.

Baffes, John, Ayhan Kose, Franziska Ohnsorge and Marc Stocke, 2015. The Great Plunge in Oil Prices: Causes, Consequence and Policy Responses. World Bank Policy Research Note.

Bernanke, Ben, 2005. Sandridge Lecture, Virginia Association of Economists.

Betts, Caroline and Michael B. Devereux, 2000. Exchange rate dynamics in a model of pricingto-market. Journal of International Economics 50, 215-244.

Bornstein, Gideon, Per Krusell and Sergio Rebelo, 2018. Lags, Costs, and Stocks: An Equilibrium Model of the Oil Industry. Working Paper, Northwestern University.

Caldara, Dario, Michele Cavallo and Matteo Iacoviello, 2017. Oil Price Elasticities and Oil Price Fluctuations. Working Paper, Federal Reserve Board.

Dieppe, Alastair, Georgios Georgiadis, Martino Ricci, Ine Van Robays and Björn van Roye, 2018. ECB-Global: Introducing the ECB's Global Macroeconomic Model for Spillover analysis. Economic Modelling 72, 78-98.

European Central Bank, 2010. Energy Markets and the European Macroeconomy. ECB Occasional Paper 113.

Finn, Mary, 1995. Variance Properties of Solow's Productivity Residual and Their Cyclical Implications. Journal of Economic Dynamics \& Control 19, 1249-1281.

Finn, Mary, 2000. Perfect Competition and the Effects of Energy Price Increases on Economic Activity. Journal of Money, Credit and Banking 32, 400-416.

Forni, Lorenzo, Andrea Gerali, Alessandro Notarpietro and Massimiliano Pisani, 2015. Euro Area, Oil and Global Shocks: An Empirical Model-Based Analysis. Journal of Macroeconomics 46, 295-314.

Gars, Johan and Conny Olovsson, 2017. International Business Cycles: Quantifying the Effects of a World Market for Oil. Working Paper, Riksbank (Sweden).

in't Veld, Jan, Robert Kollmann, Beatrice Pataracchia, Marco Ratto and Werner Roeger, 2014. International Capital Flows and the Boom-Bust Cycle in Spain. Journal of International Money and Finance 48, 314-335.

Jacks, David, 2013. From Boom to Bust: A Typology of Real Commodity Prices in the Long Run. NBER Working Paper 18874.

Jacks, David, 2016. Chartbook for "From Boom to Bust", Working Paper, Simon Fraser University.

Kilian, Lutz, Alessandro Rebucci and Nikola Spatafora, 2009. Oil shocks and external balances. Journal of International Economics 77, 181-194.

Kilian, Lutz and Bruce Hicks, 2012. Did Unexpectedly Strong Economic Growth Cause the Oil Price Shock of 2003-2008? Journal of Forecasting.

Kollmann, Robert, 2002. Monetary Policy Rules in the Open Economy: Effects on Welfare and Business Cycles. Journal of Monetary Economics 49, 989-1015.

Kollmann, Robert, 2004. Welfare Effects of a Monetary Union: the Role of Trade Openness. Journal of the European Economic Association 2, 289-301.

Kollmann, Robert, Jan in't Veld, Marco Ratto, Werner Roeger and Lukas Vogel, 2015. What Drives the German Current Account? And How Does it Affect Other EU Member States? Economic Policy 40, 47-93. 
Kollmann, Robert, Beatrice Pataracchia, Marco Ratto, Werner Roeger and Lukas Vogel, 2016. The Post-Crisis Slump in the Euro Area and the US: Evidence from an Estimated Three-Region DSGE Model. European Economic Review 88, 21-41.

McKibbin, Warwick and Jeffery Sachs, 1991. Global Linkages. The Brookings Institution.

McKibbin, Warwick and Andrew Stoeckel, 2018. Modelling a Complex World: Improving Macro-Models. Oxford Review of Economic Policy 34, 329-347.

Miura, Shogo, 2017. World Price Shocks and Business Cycles. Working Paper, Université Libre de Bruxelles.

Obstfeld, Maurice and Kenneth Rogoff, 1996. Foundations of International Macroeconomics. MIT Press.

Peersman, Gert and Ine Van Robays, 2009. Oil and the European Economy. Economic Policy.

Ratto Marco, Werner Roeger and Jan in 't Veld, 2009. QUEST III: An Estimated Open-Economy DSGE Model of the Euro Area with Fiscal and Monetary Policy, Economic Modelling, 26, 222-33.

Sachs, Jeffrey, 1981. The Current Account and Macroeconomic Adjustment in the 1970s. Brookings Papers on Economic Activity, 201-268. 


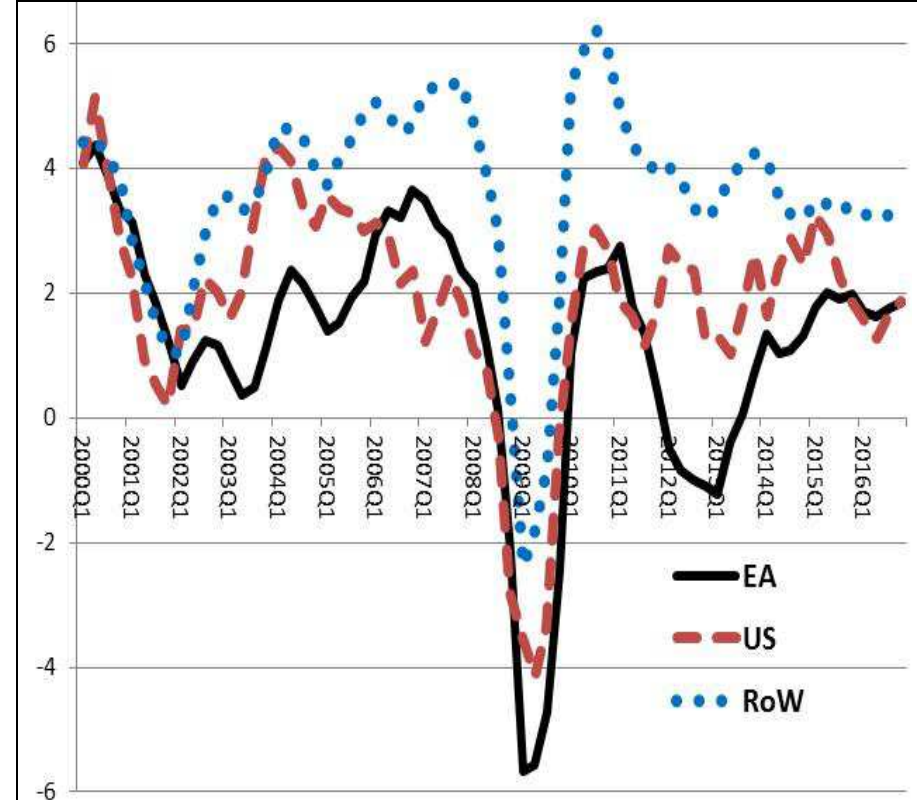

Fig. 1a. Growth rate of real GDP (year-on-year, in \%)

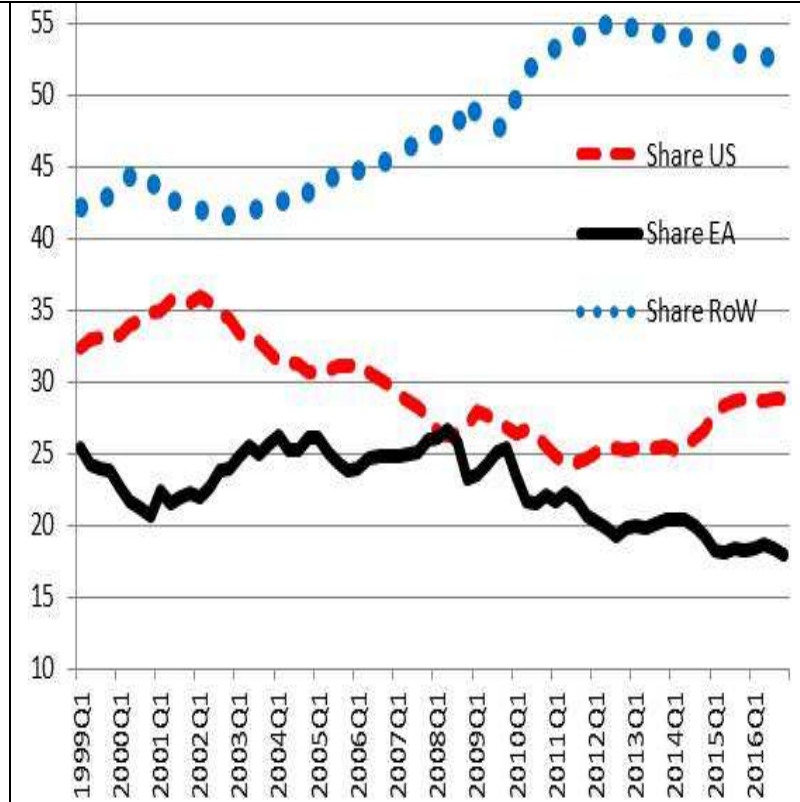

Fig. 1b. Shares in World nominal GDP (in US dollars, based on nom. exch.rates)

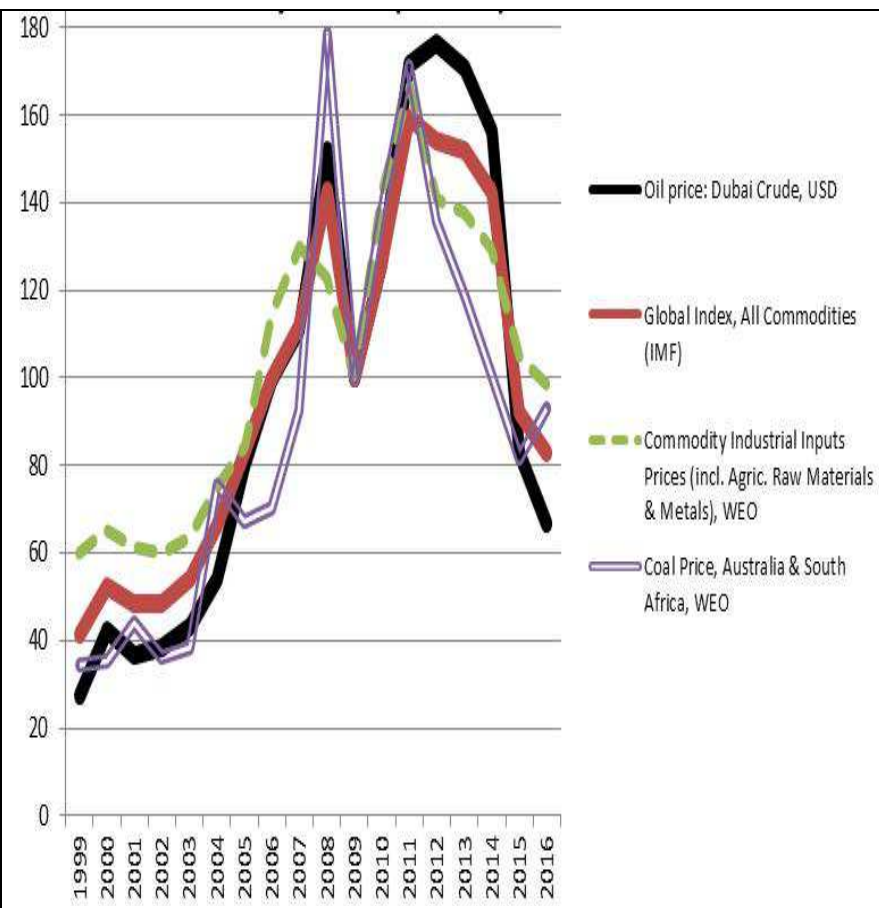

Fig. 2a. Commodity prices (in dollars, 2009=100)

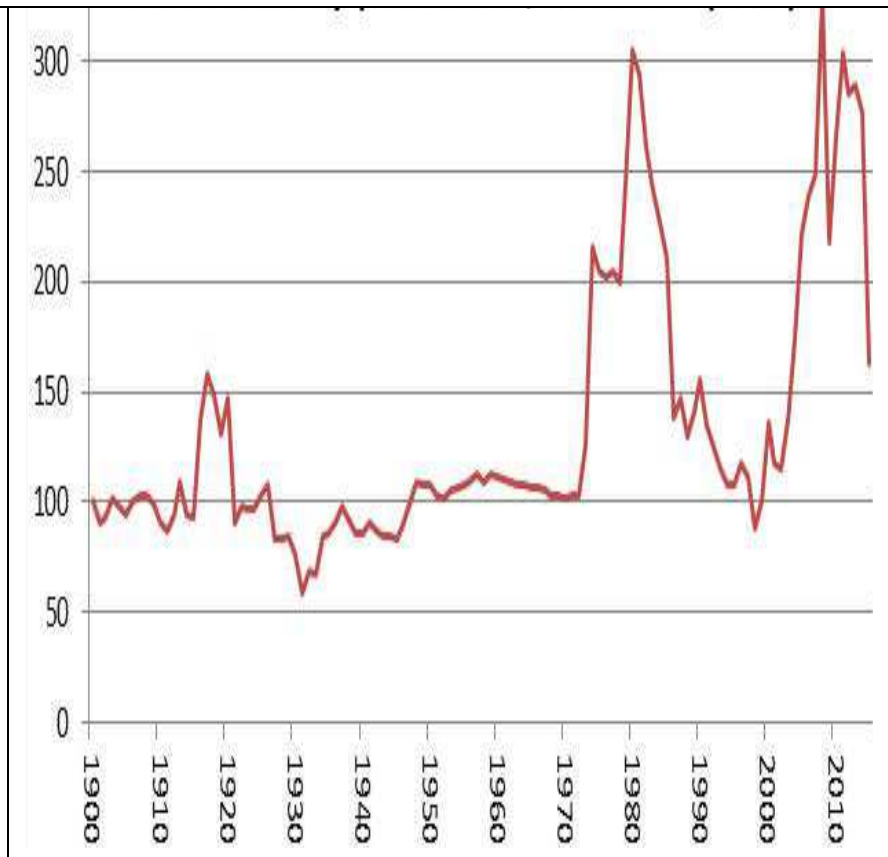

Fig. 2b. Real commodity price index, $1900=2015$ (40 commodities; deflator: US CPI), $1900=100$. Source: Jacks (2013, 2016) 


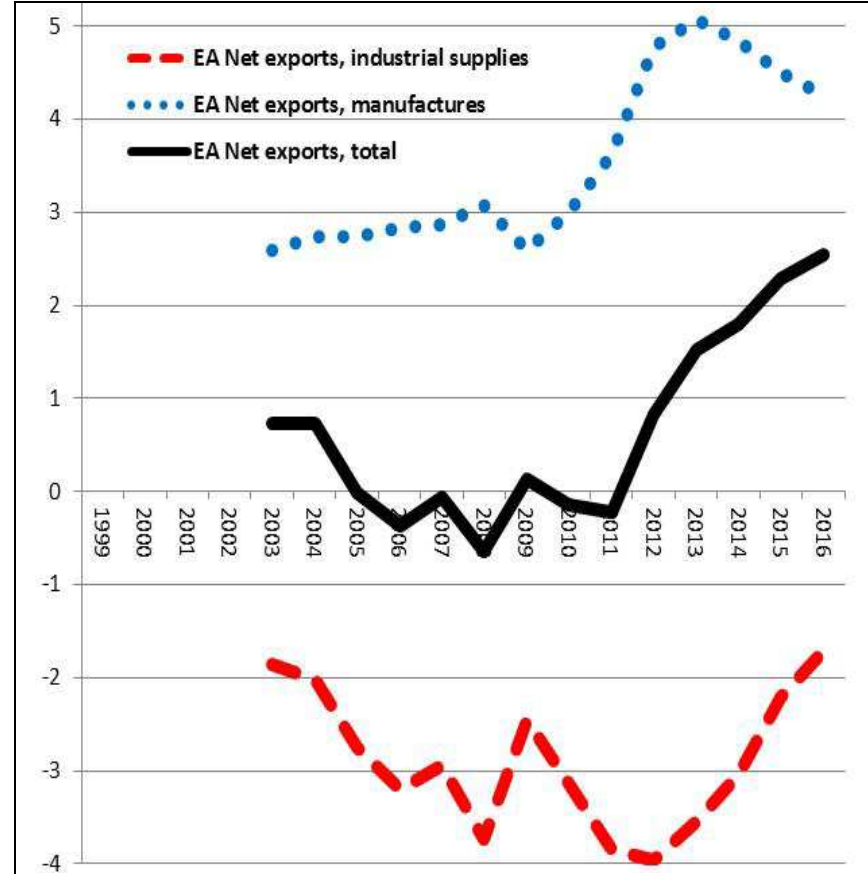

Fig. 3a.EA Net exports by product (in \% EA GDP) Note: these series are only available for 2003- (annual).

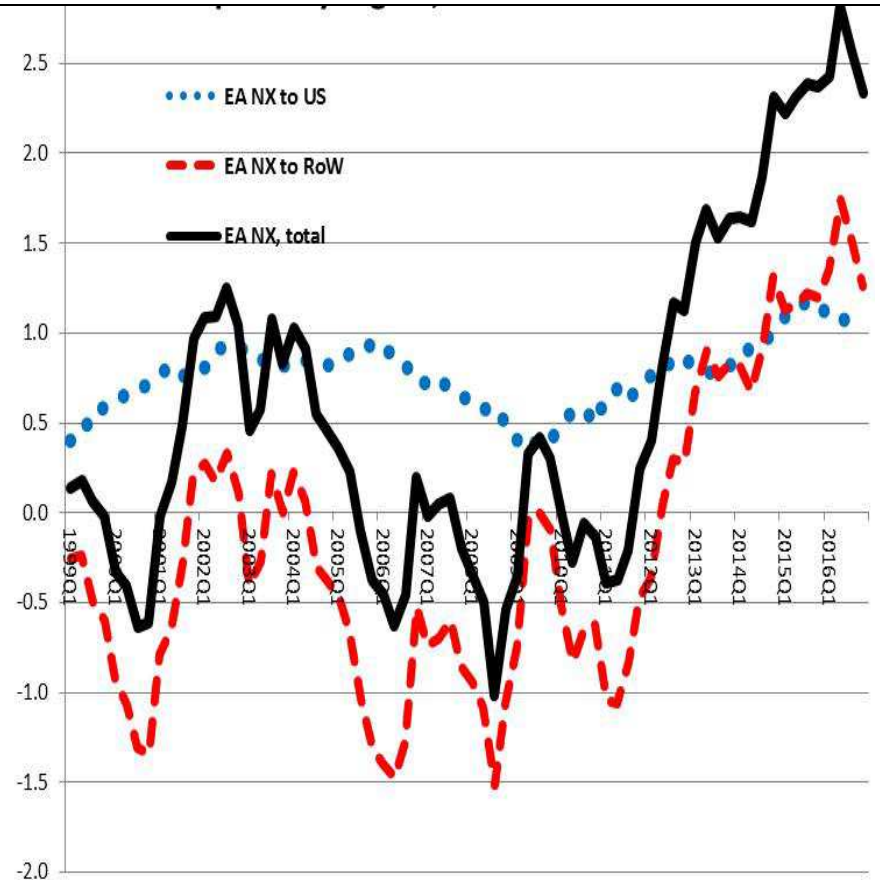

Fig.3b.EA Net exports by region (in \% EA GDP)

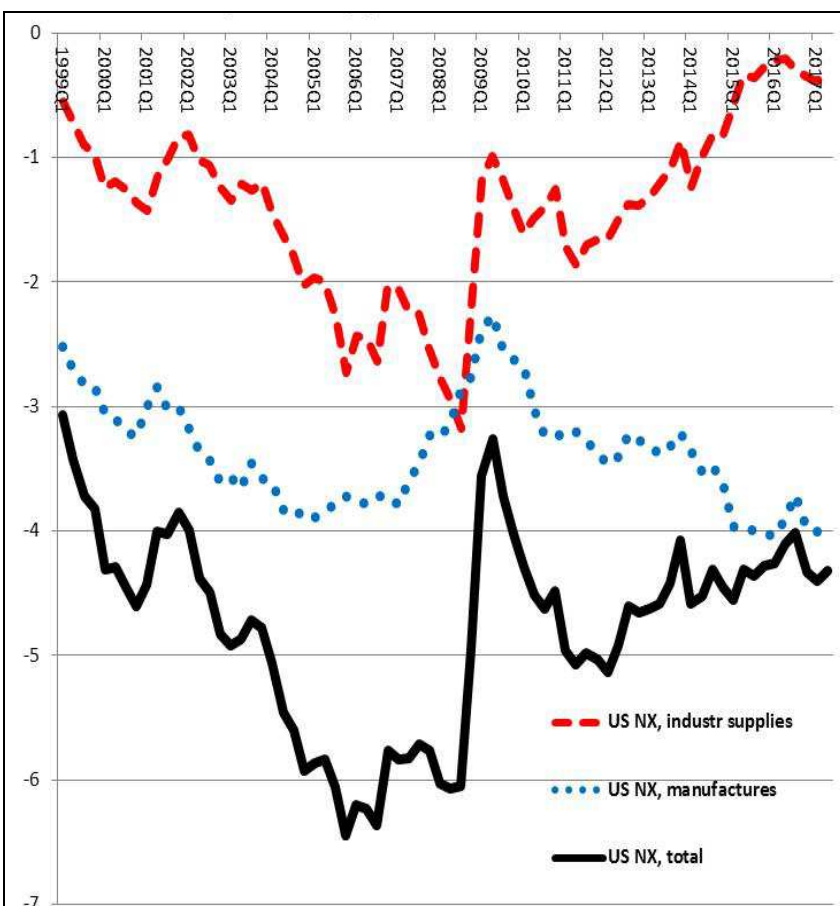

Fig.3c. US Net exports by product (in \% US GDP)

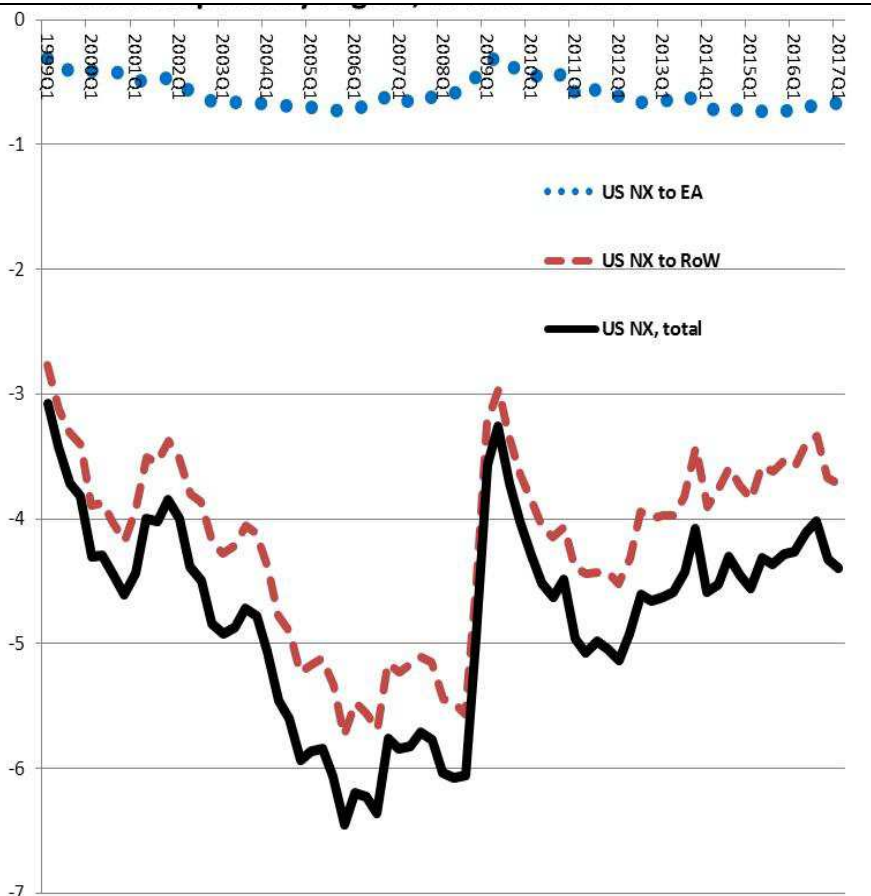

Fig.3d. US Net exports by region (in \% US GDP) 

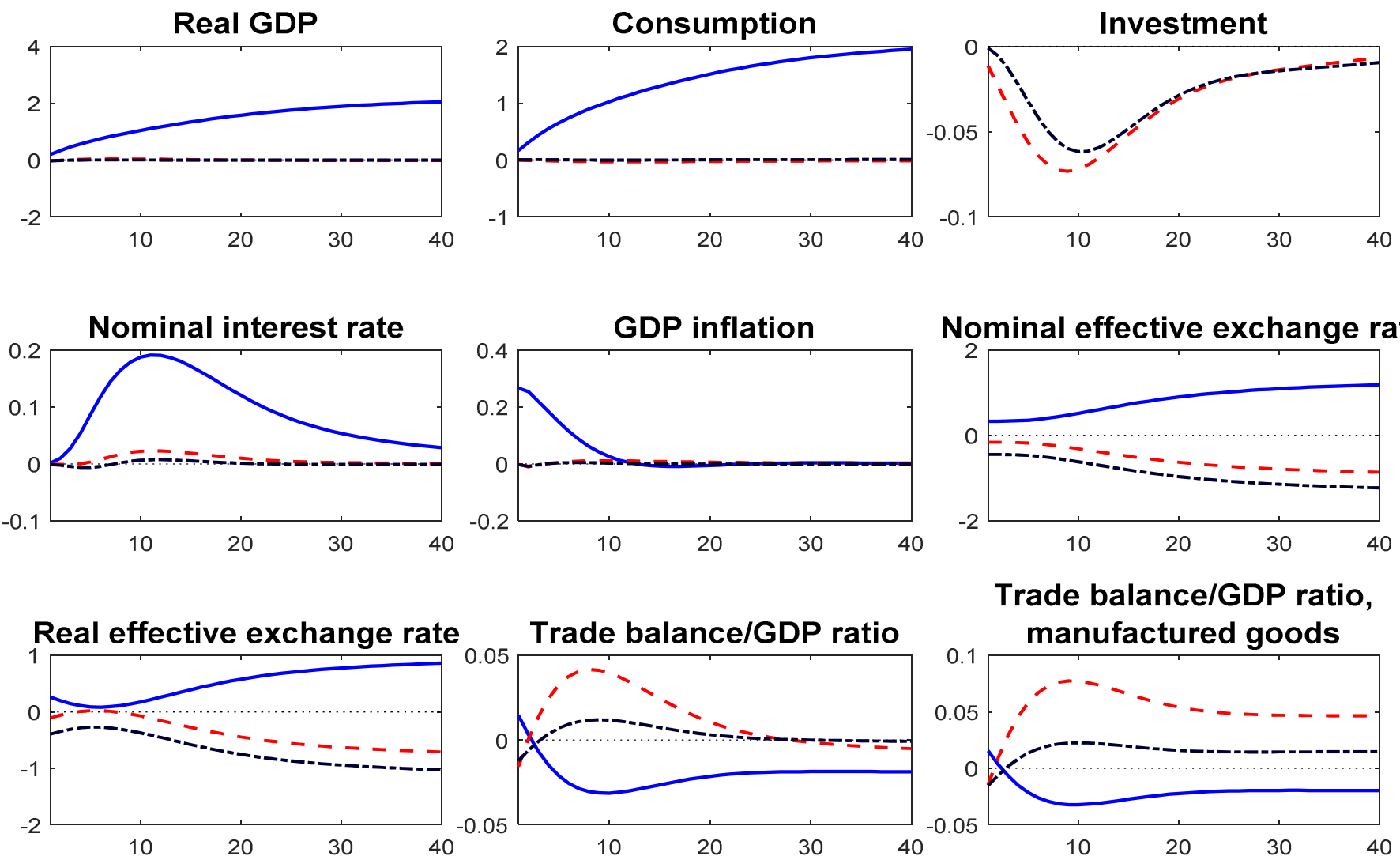

Trade balance/GDP ratio, manufactured goods

Terms of trade,

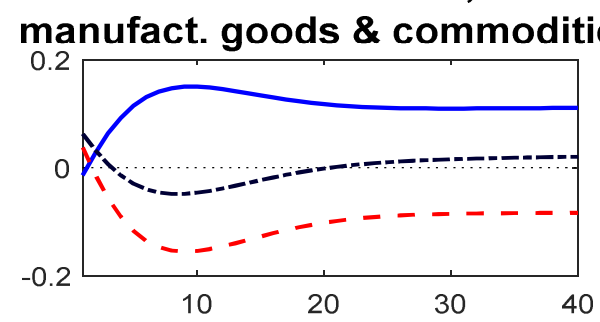

Terms of trade,

manufactured goods
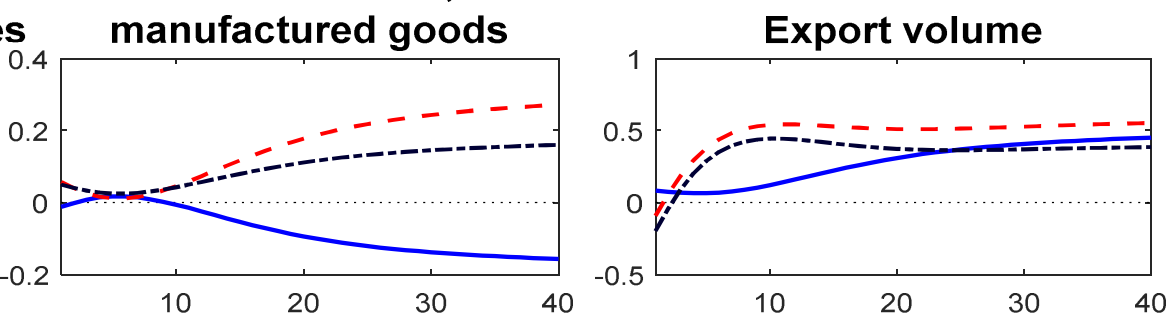

Commodity price
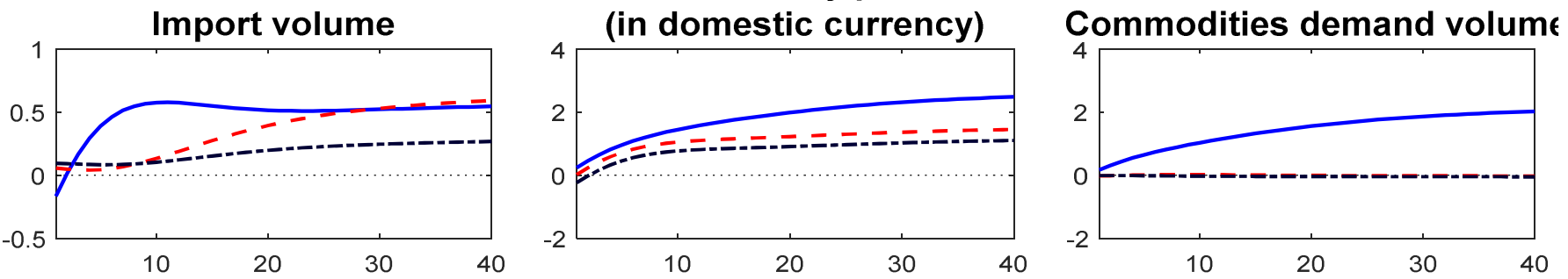

RoW

EA - - -

US

Fig. 4a Dynamic effects of positive shock to trend growth rate of RoW TFP (1 standard deviation) Note: Trade balance (normalized by GDP), inflation (p.a.) and interest rate (p.a.) responses are expressed as percentage point responses from unshocked paths. Other responses are percent responses from unshocked paths. A fall in the exchange rate represents an appreciation. Horizontal axis: quarters after shock. The responses of RoW, EA and US variables are represented by blue, red and black lines, respectively. 

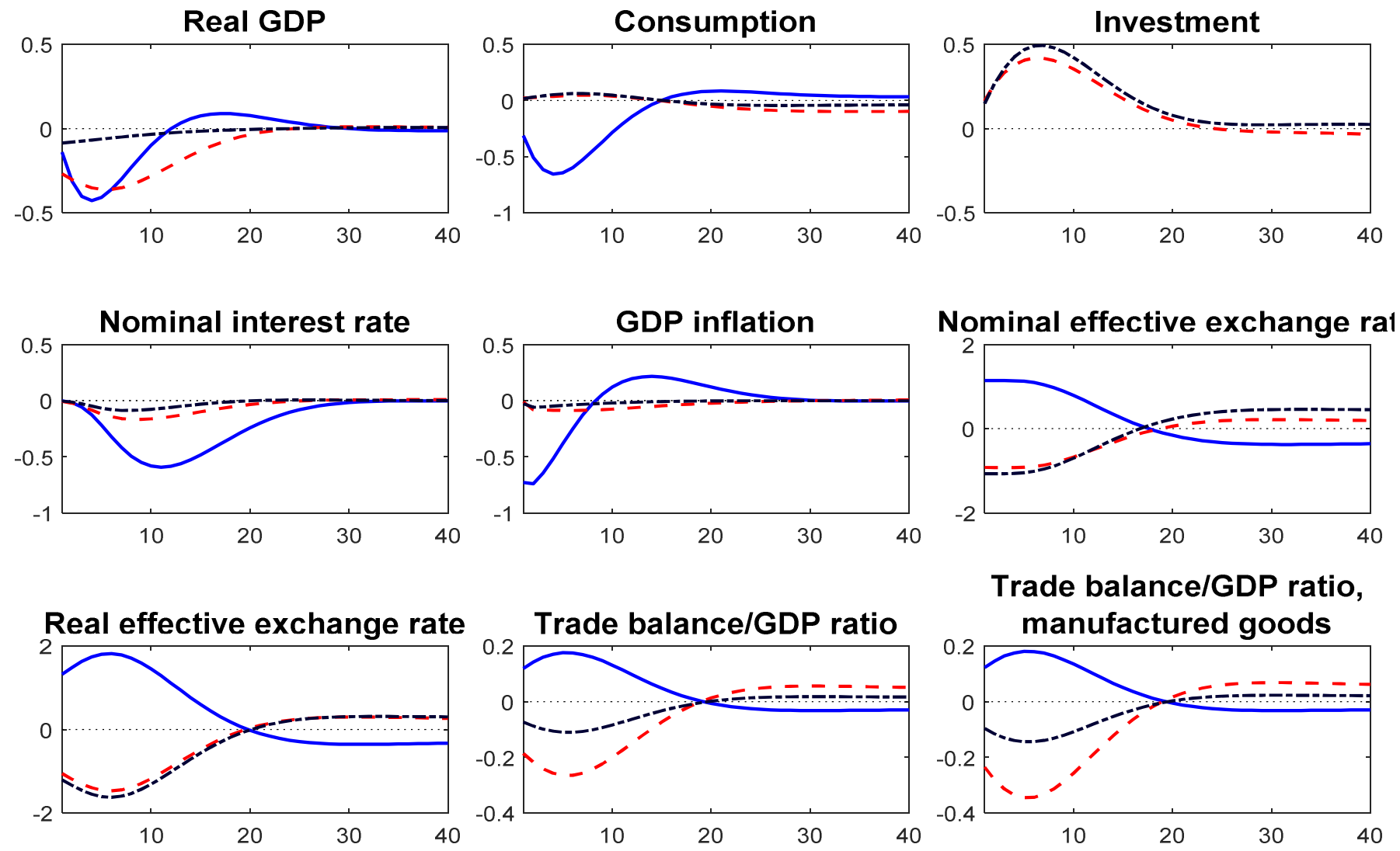

Trade balance/GDP ratio, manufactured goods

Terms of trade,

Terms of trade,
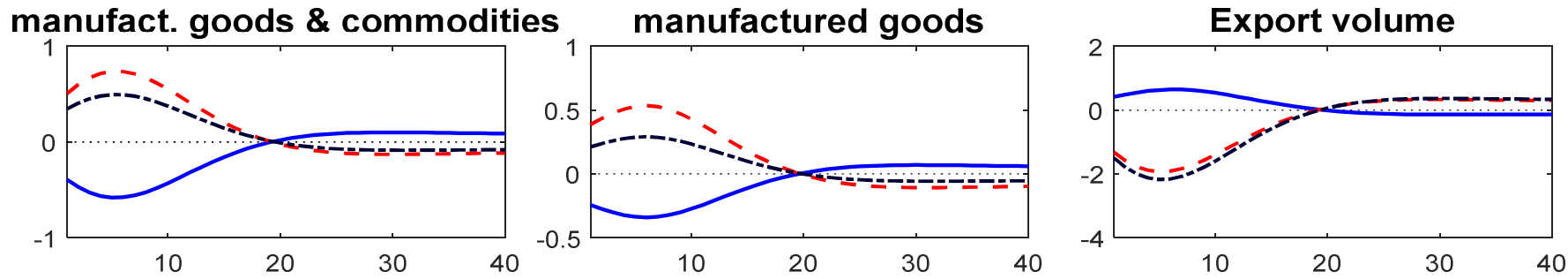

Commodity price
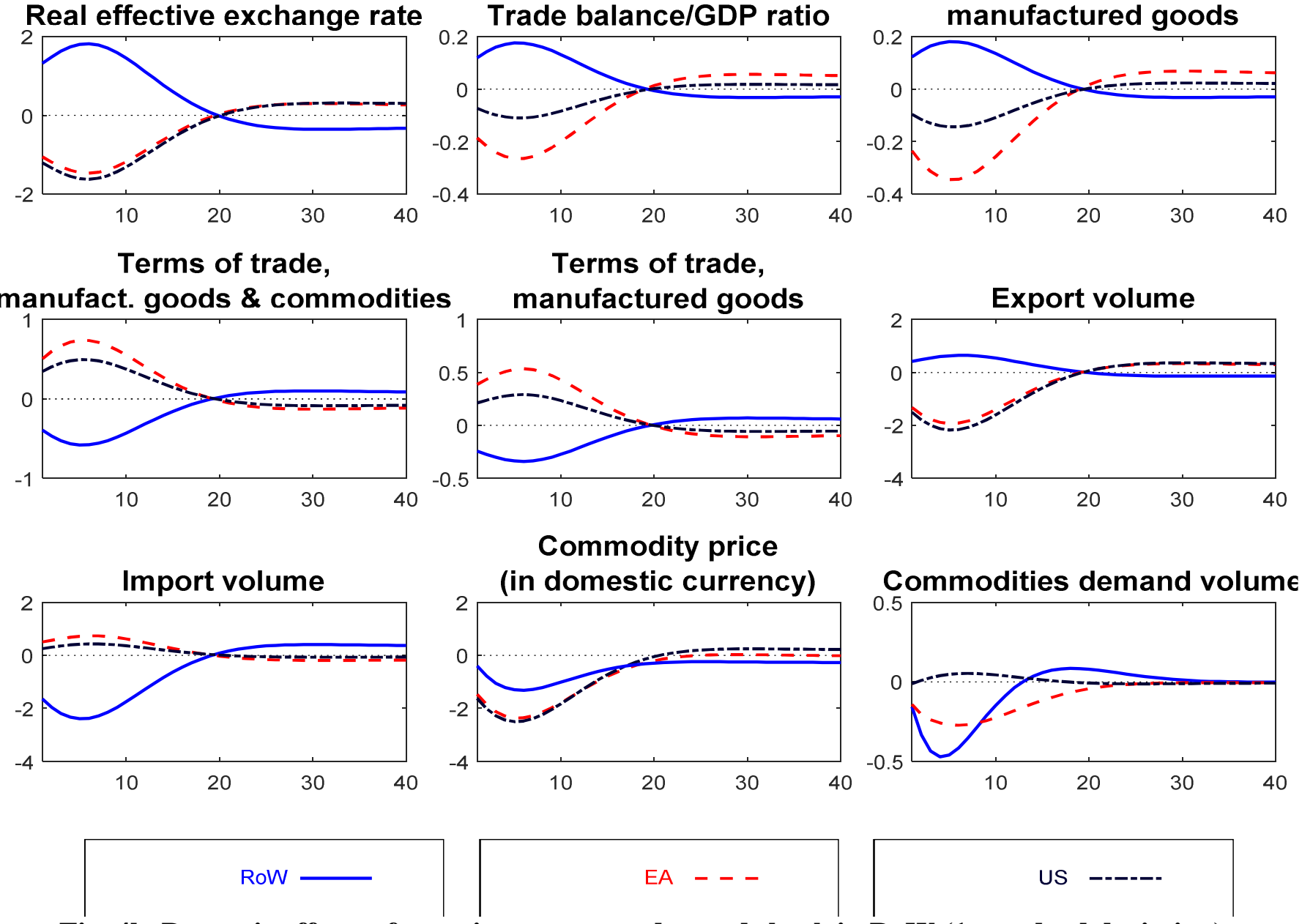

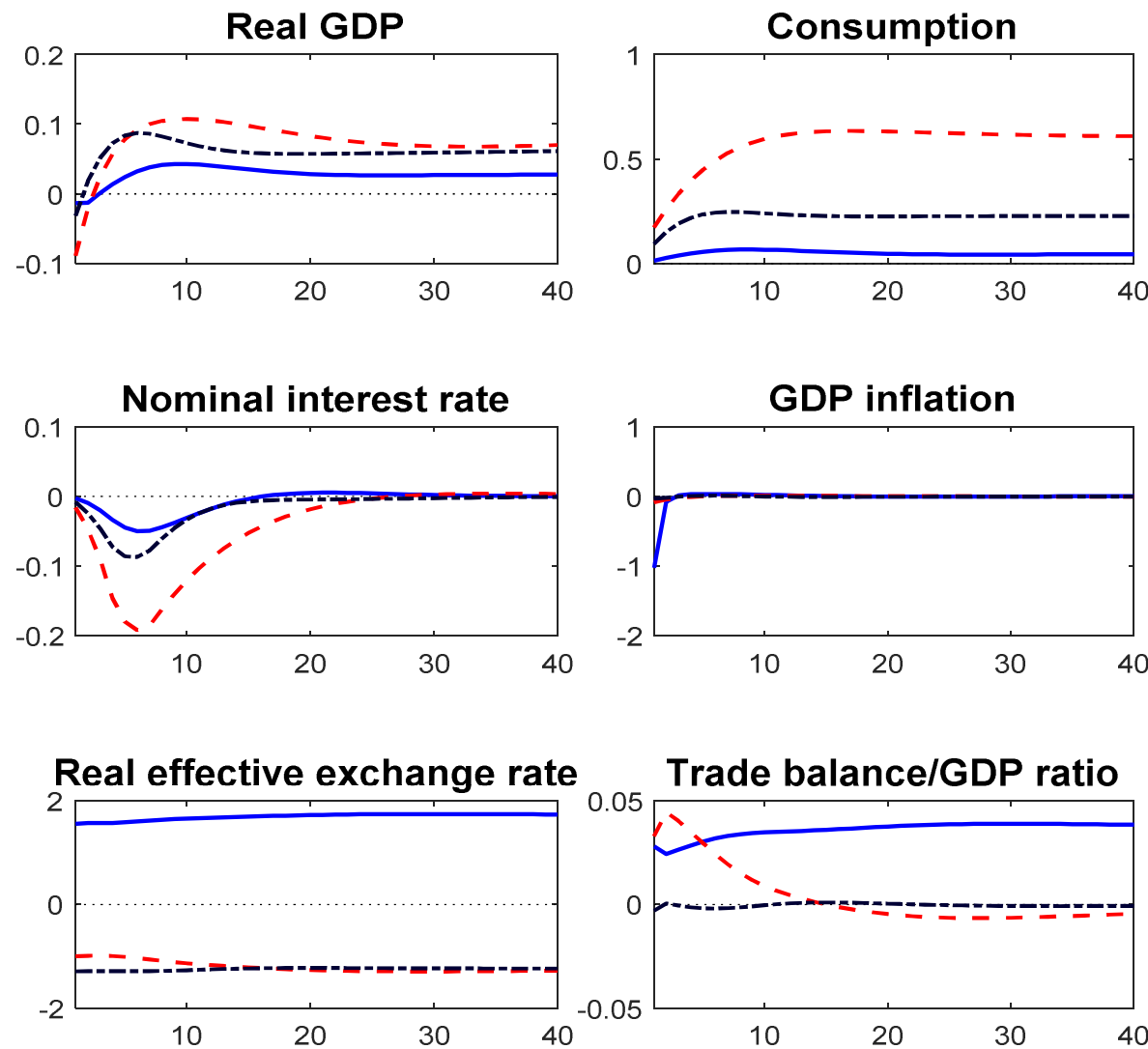

Terms of trade,
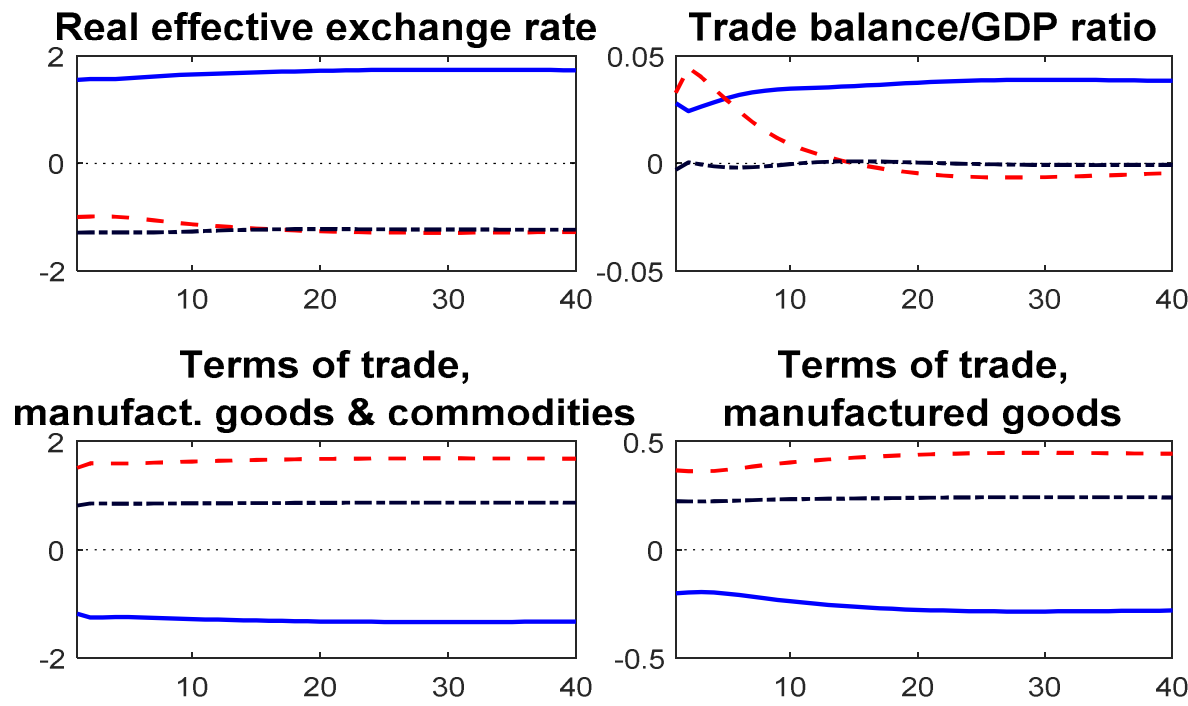

Terms of trade, manufactured goods
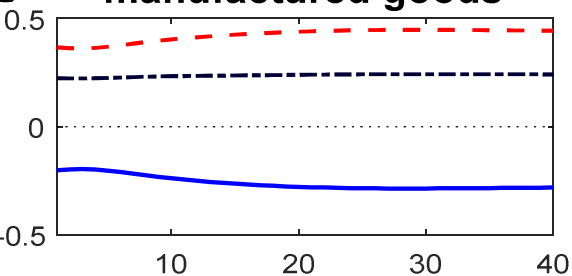

Commodity price
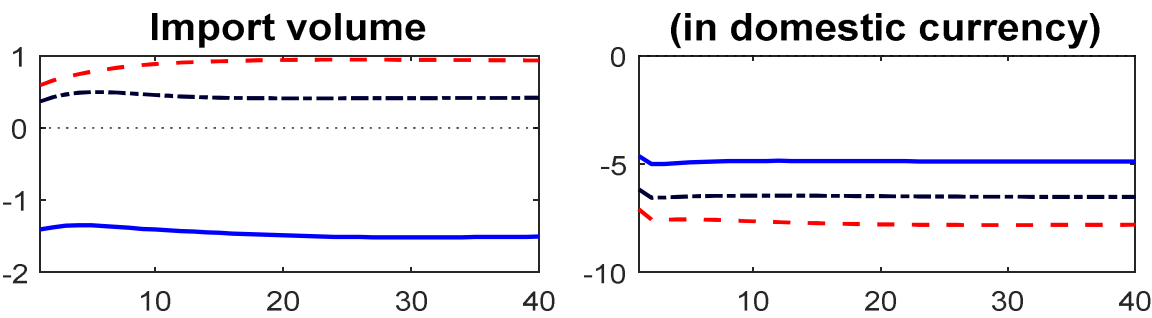

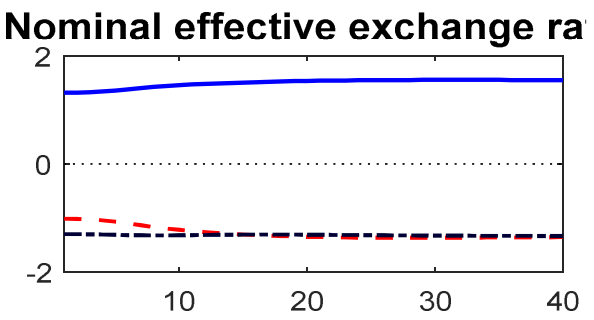

Trade balance/GDP ratio, manufactured goods
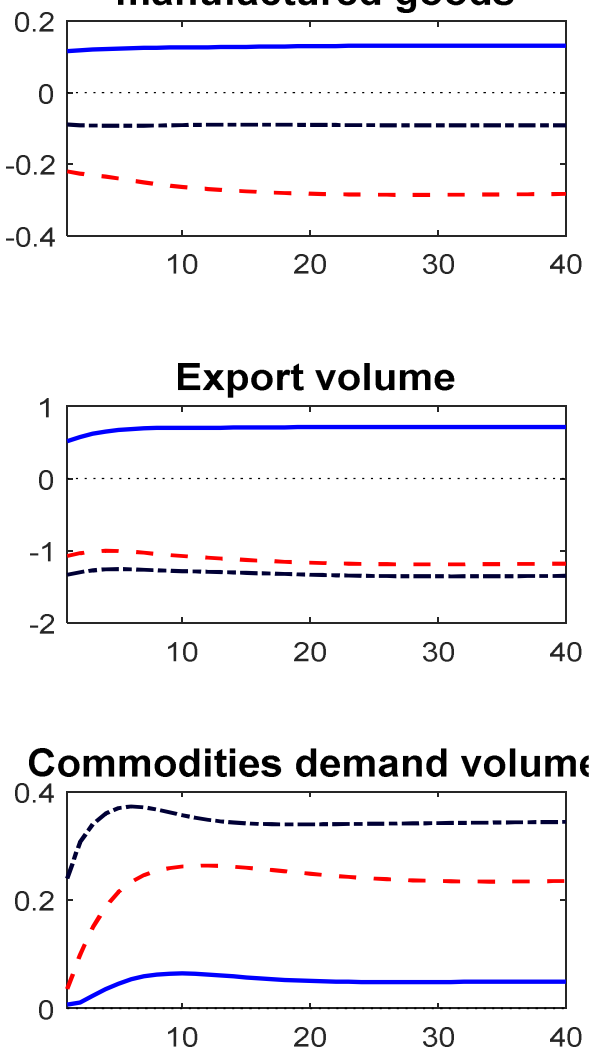

US

RoW

EA - - -

Fig. 4c. Dynamic effects of positive shock to RoW commodity supply (1 standard deviation)

Note: Trade balance (normalized by GDP), inflation (p.a.) and interest rate (p.a.) responses are expressed as percentage point responses from unshocked paths. Other responses are percent responses from unshocked paths. A fall in the exchange rate represents an appreciation. Horizontal axis: quarters after shock. The responses of RoW, EA and US variables are represented by blue, red and black lines, respectively. 

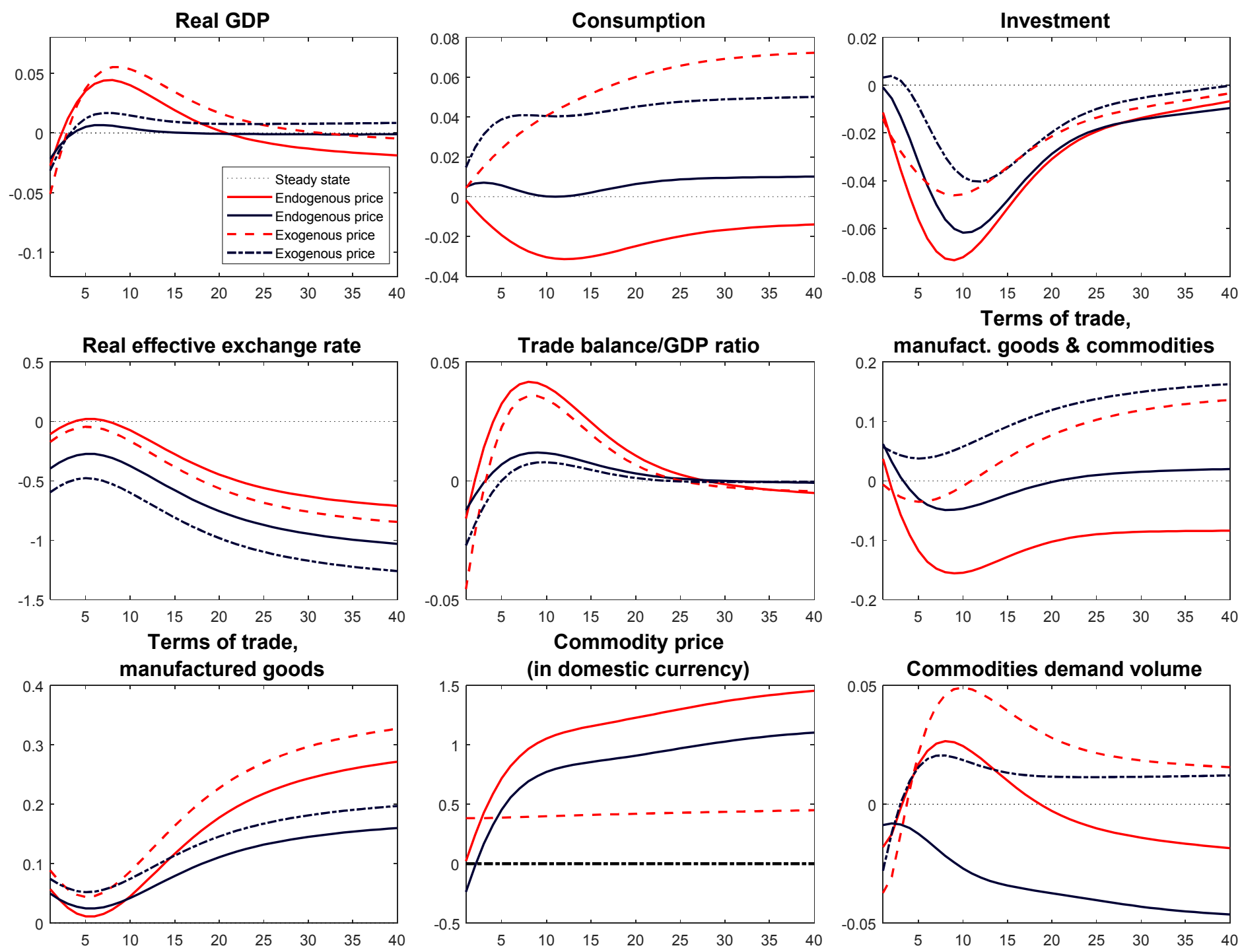

EA - - - -

US

Fig. 4d. Dynamic effects of a positive shock to trend growth rate of RoW TFP (1 standard deviation) on EA and US variables: comparison of baseline model (flexible commodity prices) vs. model version with fixed commodity prices (in dollars)

Note: Trade balance (normalized by GDP) responses are expressed as percentage point responses from unshocked paths. Other responses are percent responses from unshocked paths. A fall in the exchange rate represents an appreciation. Horizontal axis: quarters after shock. Continues lines (labelled 'endogenous price') show responses in the baseline model (that assumes a flexible commodity price); dashed lines (labelled 'exogenous price') show responses in a model variant in which commodity prices, in US dollars, do not respond to the shock. EA and US variables are represented by red and black lines, respectively. 

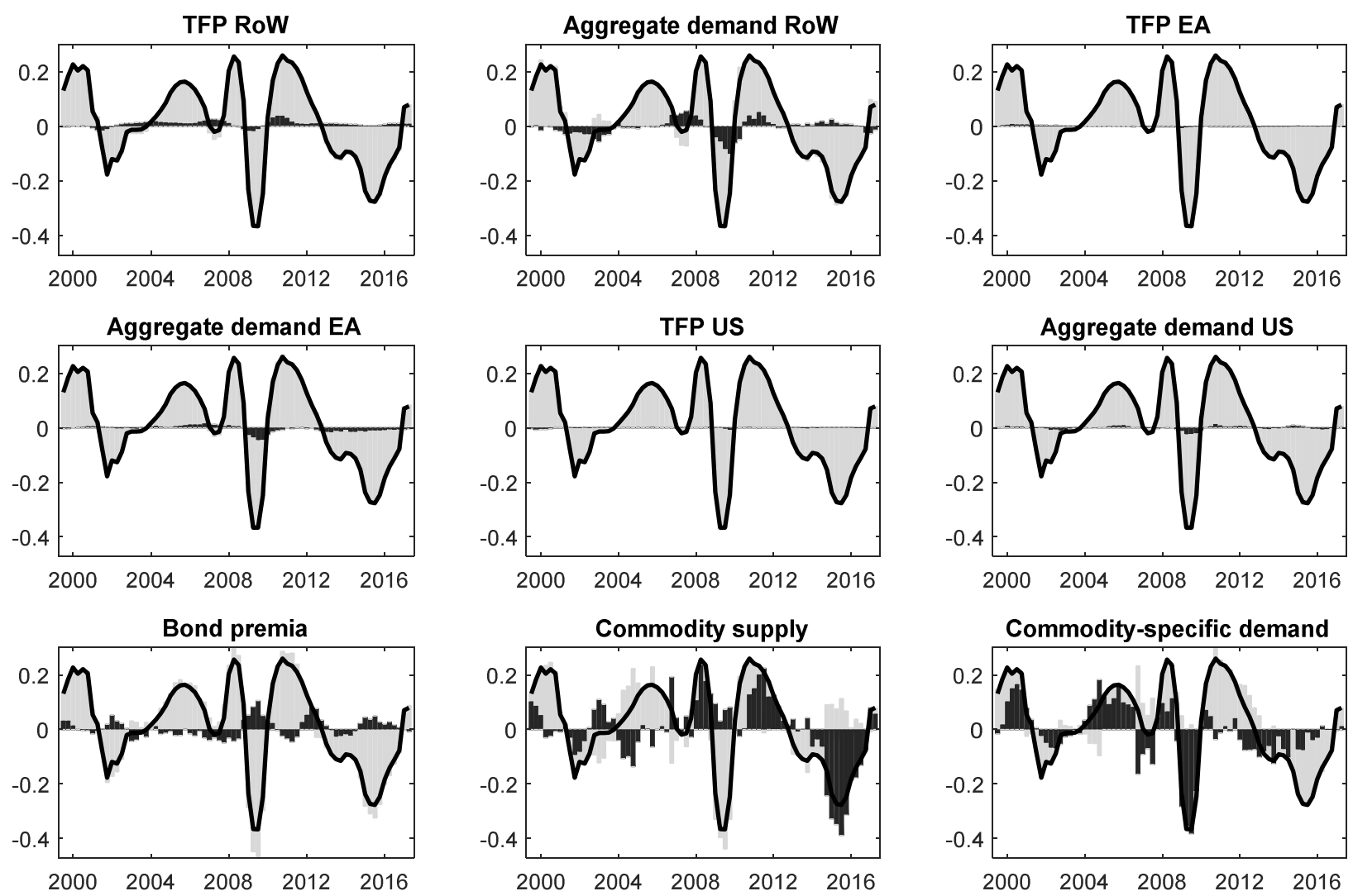

Fig. 5a. Historical shock decomposition: Industrial supplies price, in Euro (yoy growth rate)
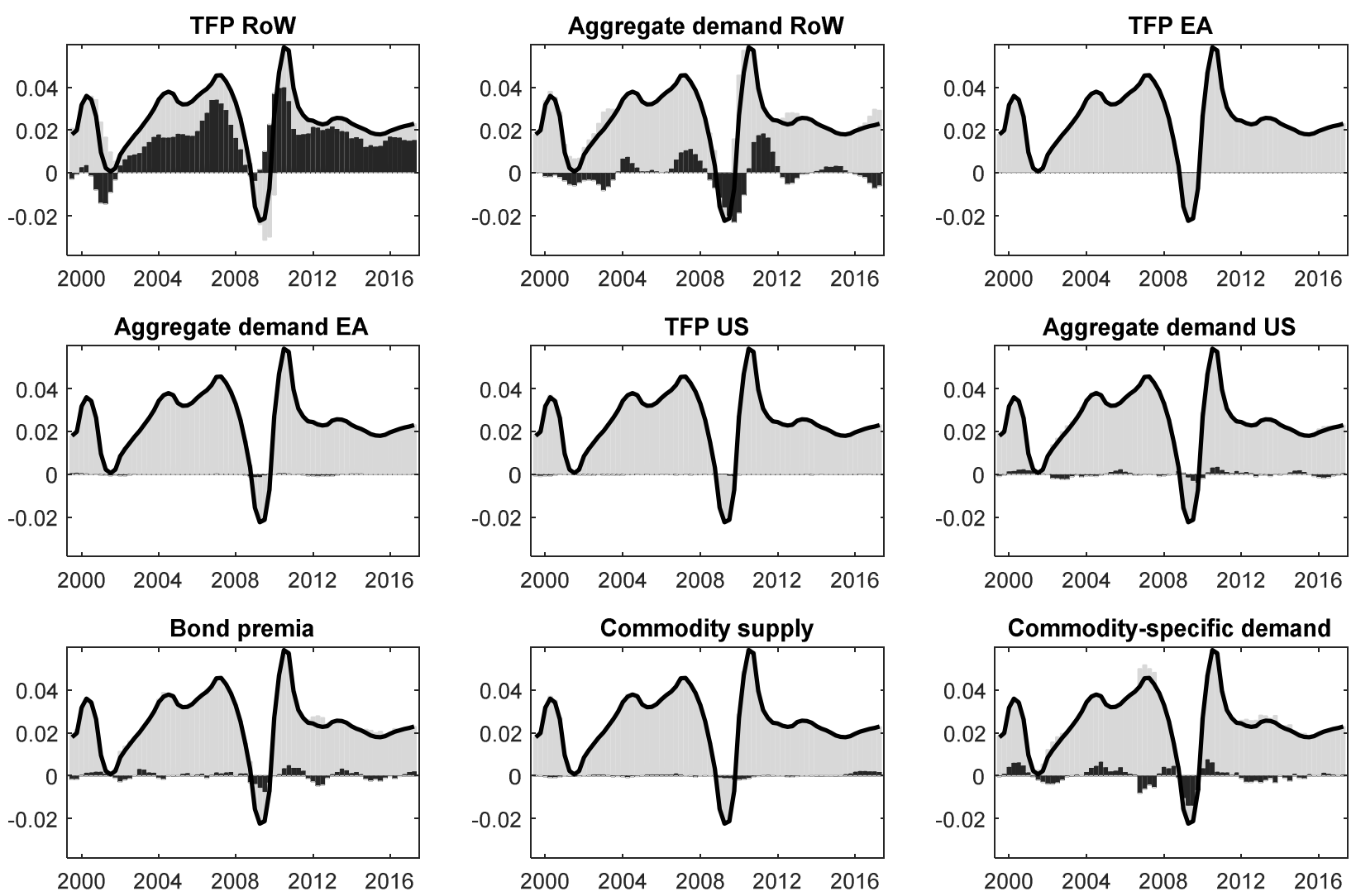

Fig. 5b. Historical shock decomposition: RoW GDP growth (yoy) 

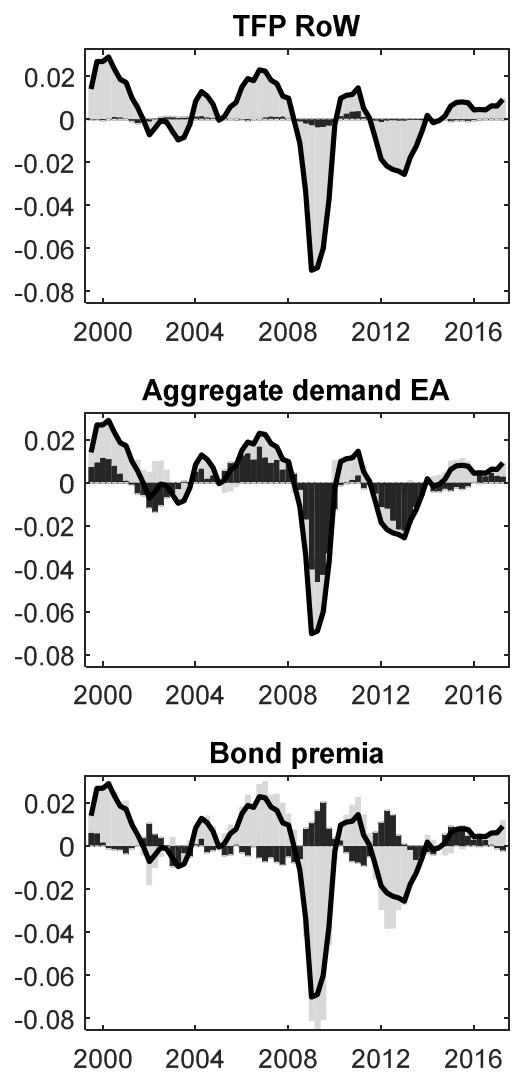
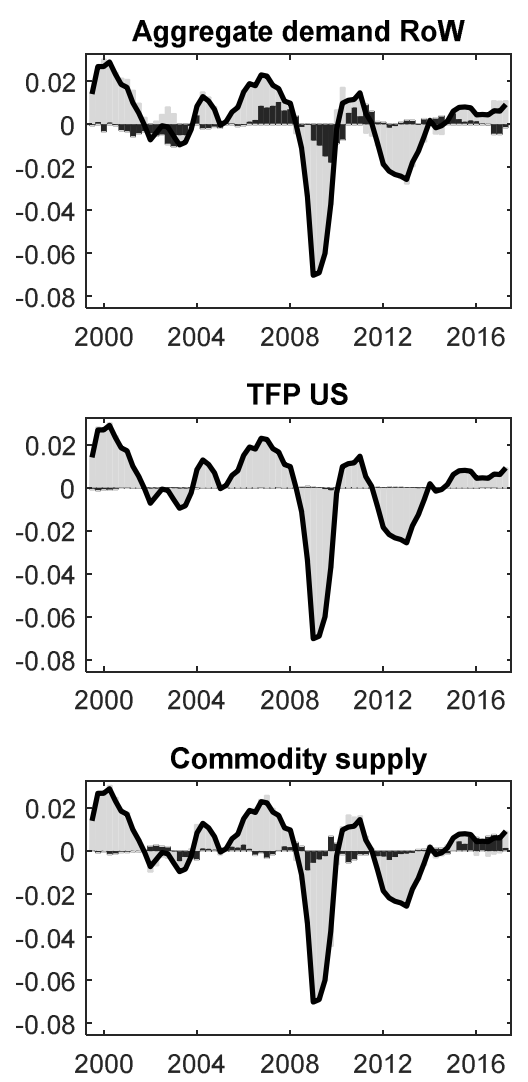

Fig. 5c. Historical shock decomposition: EA GDP growth (yoy)
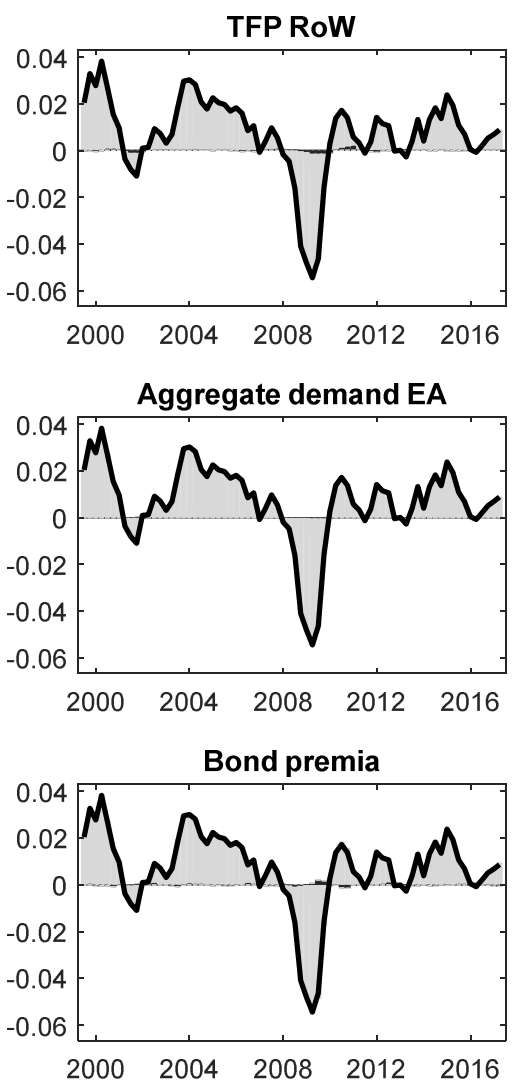
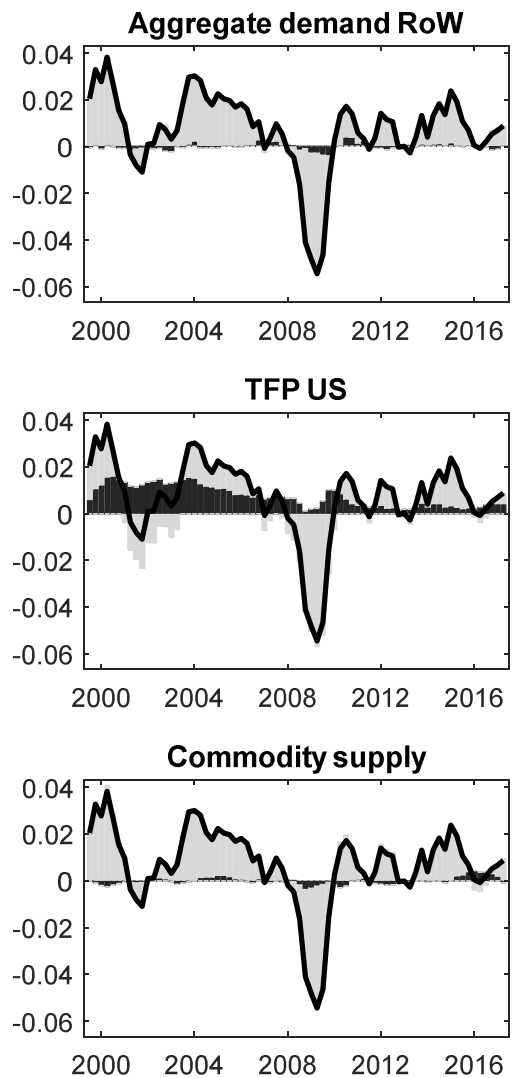
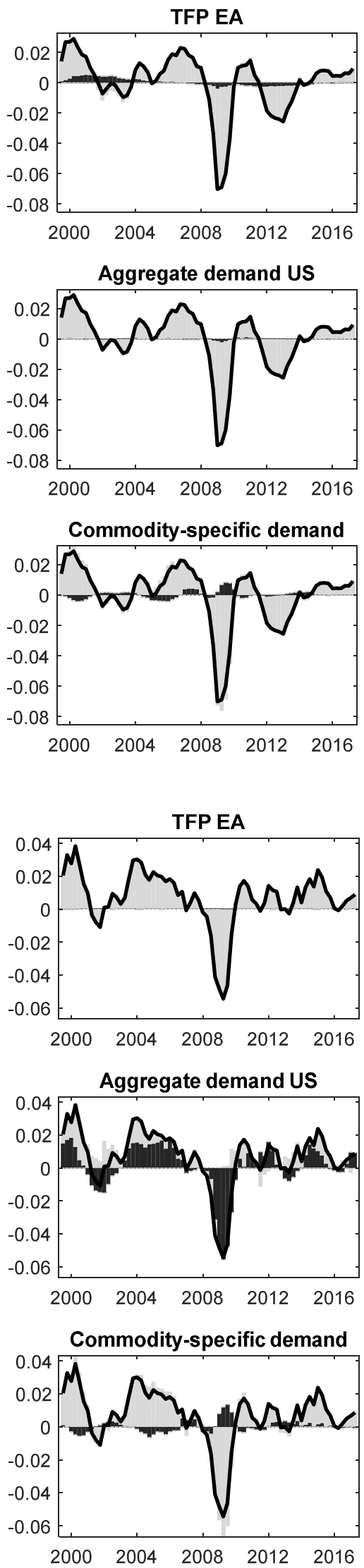

Fig. 5d. Historical shock decomposition: US GDP growth (yoy) 

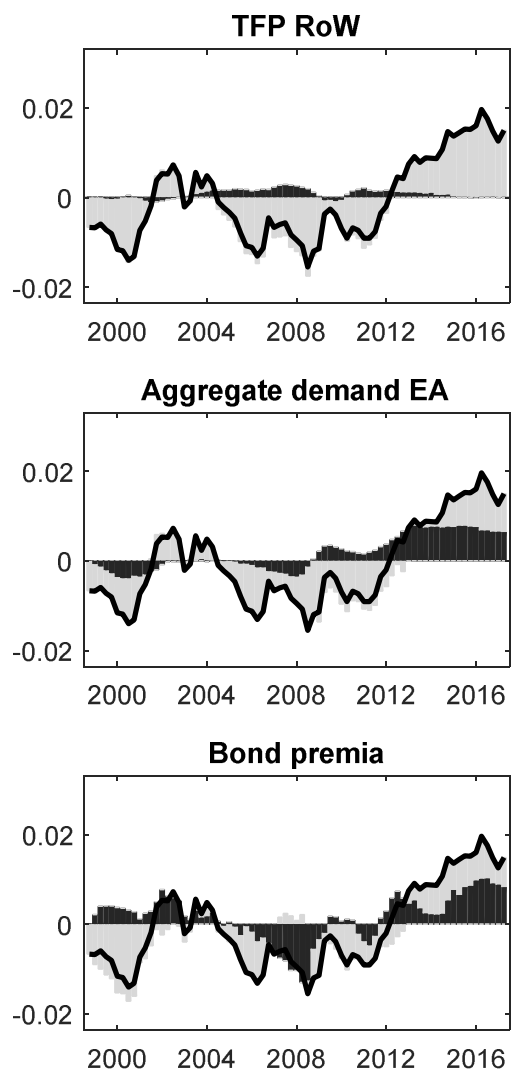

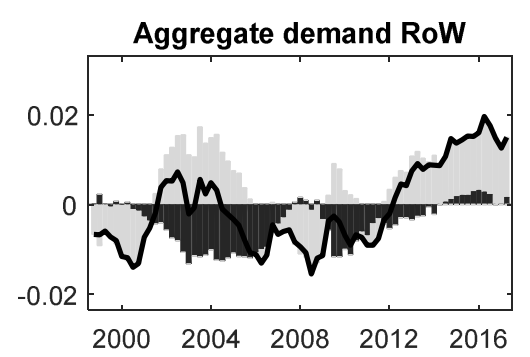

TFP US
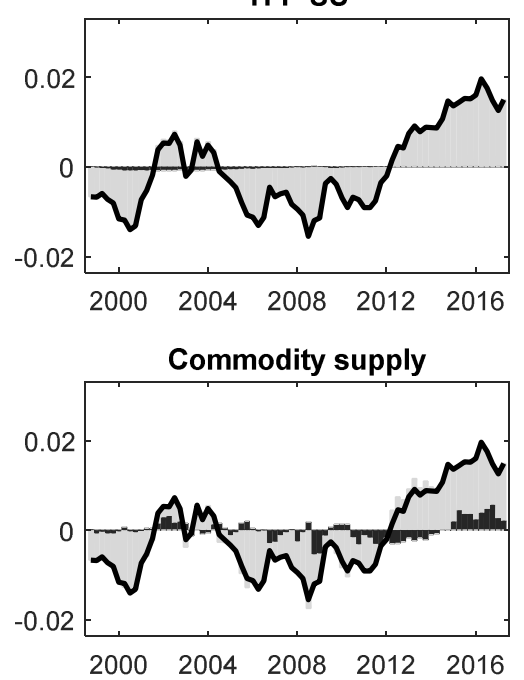

TFP EA
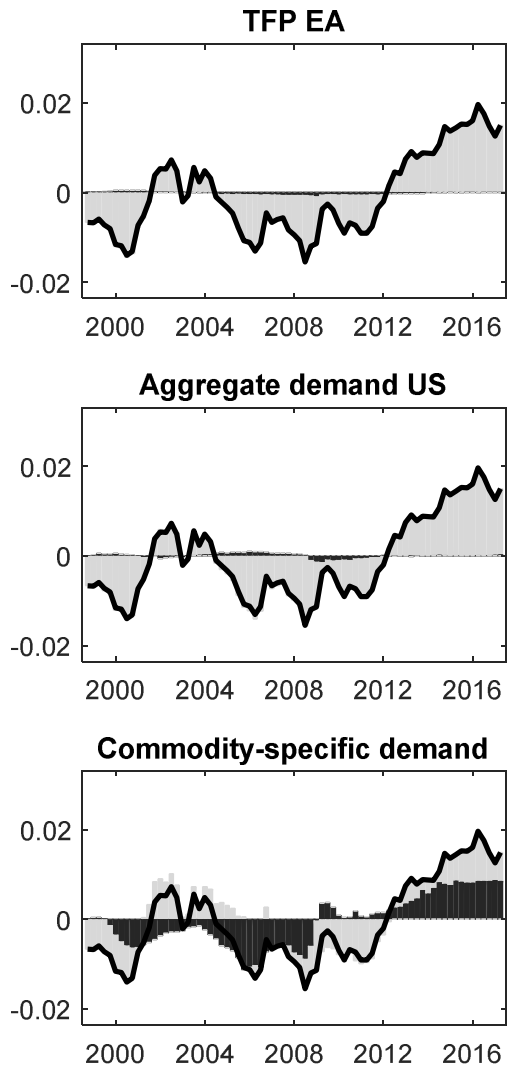

Fig. 5e. Historical shock decomposition: EA trade balance/GDP ratio
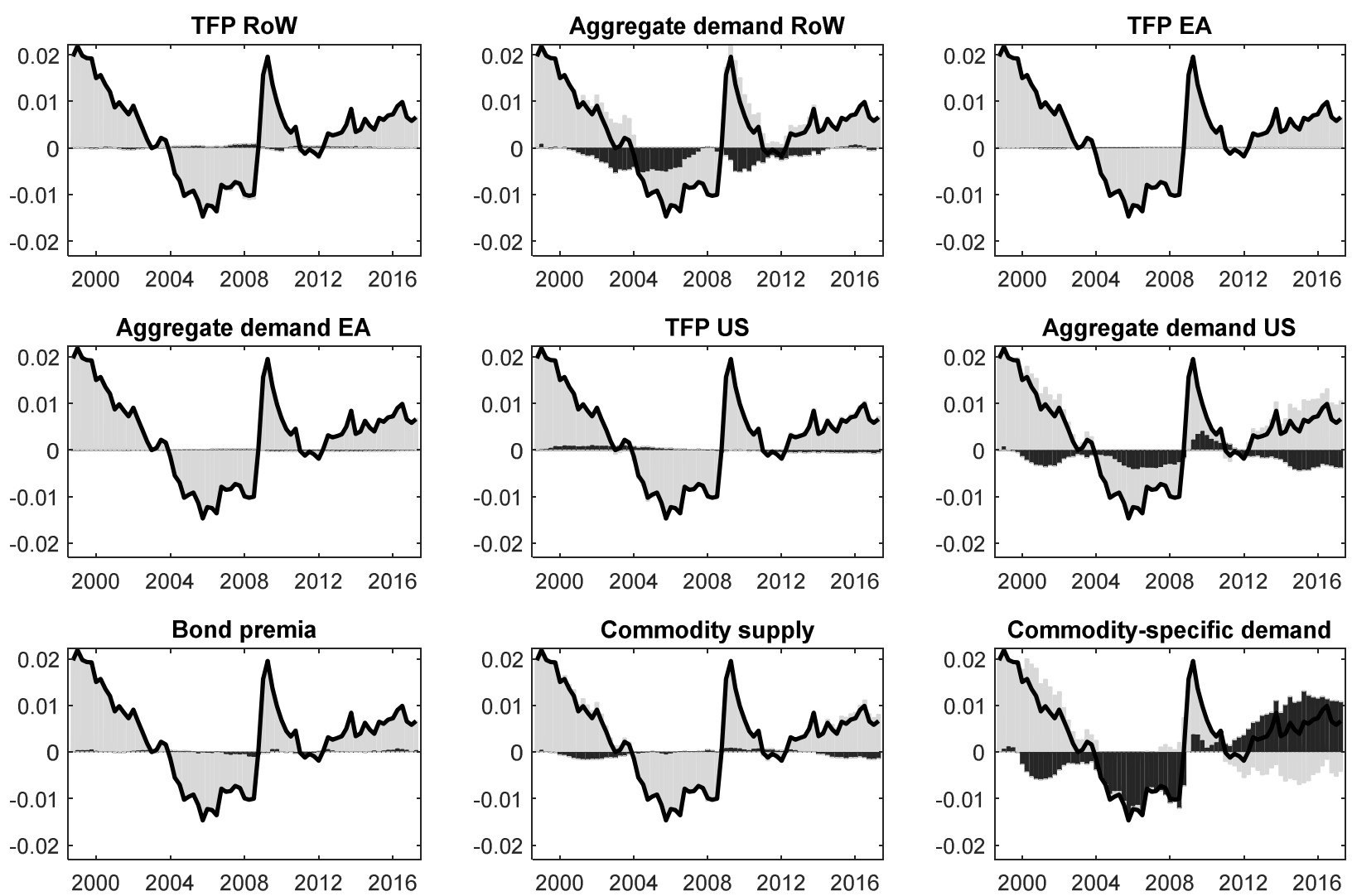

Fig. 5f. Historical shock decomposition: US trade balance/GDP ratio 
Table 1. Prior and posterior distributions of key estimated model parameters

\begin{tabular}{|c|c|c|c|c|c|c|c|}
\hline & \multicolumn{4}{|c|}{ Posterior distributions } & \multirow{2}{*}{\multicolumn{3}{|c|}{ Prior distributions }} \\
\hline & \multicolumn{2}{|c|}{ EA } & \multicolumn{2}{|c|}{ US } & & & \\
\hline & Mode & Std & Mode & Std & Distrib. & Mean & Std \\
\hline$(1)$ & $(2)$ & $(3)$ & $(4)$ & $(5)$ & (6) & $(7)$ & $(8)$ \\
\hline \multicolumn{8}{|l|}{ Preferences and technologies } \\
\hline Consumption habit persistence & 0.86 & 0.03 & 0.71 & 0.07 & $\mathrm{~B}$ & 0.5 & 0.1 \\
\hline Risk aversion & 1.74 & 0.20 & 1.68 & 0.55 & $\mathrm{G}$ & 1.5 & 0.2 \\
\hline Inverse labor supply elasticity & 2.40 & 0.39 & 1.91 & 0.45 & $\mathrm{G}$ & 2.5 & 0.5 \\
\hline Import price elasticity & 1.20 & 0.07 & 1.22 & 0.15 & $\mathrm{G}$ & 2 & 0.4 \\
\hline \multicolumn{8}{|c|}{ Steady state consumption share of Ricardian households } \\
\hline & 0.72 & 0.06 & 0.84 & 0.06 & $\mathrm{~B}$ & 0.5 & 0.1 \\
\hline \multicolumn{8}{|l|}{ Nominal frictions } \\
\hline Price adjustment cost & 22.3 & 7.99 & 24.7 & 6.15 & $\mathrm{G}$ & 60 & 40 \\
\hline Nominal wage adj. cost & 3.83 & 2.07 & 3.39 & 0.94 & $\mathrm{G}$ & 5 & 2 \\
\hline \multicolumn{8}{|l|}{ Monetary policy } \\
\hline Interest rate persistence & 0.87 & 0.03 & 0.83 & 0.03 & $\mathrm{~B}$ & 0.7 & 0.12 \\
\hline Response to inflation & 1.30 & 0.31 & 1.38 & 0.31 & $\mathrm{~B}$ & 2 & 0.4 \\
\hline Response to GDP & 0.05 & 0.02 & 0.07 & 0.02 & $\mathrm{~B}$ & 0.5 & 0.2 \\
\hline \multicolumn{8}{|l|}{ Commodities } \\
\hline Commodity demand elasticity & 0.02 & 0.02 & 0.05 & 0.03 & $\mathrm{~B}$ & 0.5 & 0.2 \\
\hline Inverse commodity supply elastic & city $(\mathrm{Rc}$ & & 1.07 & 0.15 & $\mathrm{~B}$ & 3.00 & 1.5 \\
\hline \multicolumn{8}{|c|}{ Autocorrelations of forcing variables } \\
\hline Permanent TFP growth & 0.95 & 0.03 & 0.92 & 0.03 & $\mathrm{~B}$ & 0.85 & 0.075 \\
\hline Subjective discount factor & 0.78 & 0.05 & 0.97 & 0.30 & B & 0.5 & 0.2 \\
\hline Investment risk premium & 0.96 & 0.02 & 0.95 & 0.02 & B & 0.85 & 0.05 \\
\hline Trade share & 0.98 & 0.01 & 0.92 & 0.03 & $\mathrm{~B}$ & 0.5 & 0.2 \\
\hline Commodity specific demand, $\rho_{1}$ & 1.52 & 0.13 & 1.32 & 0.10 & $\mathrm{~N}$ & 1.4 & 0.25 \\
\hline Commodity specific demand, $\rho_{2}$ & -0.57 & 0.12 & -0.38 & 0.10 & $\mathrm{~N}$ & -0.4 & 0.15 \\
\hline \multicolumn{8}{|c|}{ Standard deviations $(\%)$ of innovations to forcing variables } \\
\hline Monetary policy & 0.10 & 0.01 & 0.11 & 0.01 & $\mathrm{G}$ & 1.00 & 0.40 \\
\hline Gov. transfers & 0.09 & 0.01 & 0.47 & 0.04 & $\mathrm{G}$ & 1.00 & 0.40 \\
\hline Permanent TFP level & 0.08 & 0.01 & 0.09 & 0.01 & $\mathrm{G}$ & 0.10 & 0.04 \\
\hline Permanent TFP growth & 0.02 & 0.01 & 0.06 & 0.02 & $\mathrm{G}$ & 0.10 & 0.04 \\
\hline Subjective discount factor & 1.22 & 0.35 & 0.10 & 0.27 & $\mathrm{G}$ & 1.00 & 0.40 \\
\hline Investment risk premium & 0.16 & 0.08 & 0.13 & 0.06 & $\mathrm{G}$ & 0.10 & 0.04 \\
\hline Domestic price mark-up & 3.62 & 1.22 & 4.84 & 1.06 & $\mathrm{G}$ & 2.00 & 0.80 \\
\hline Trade share & 3.39 & 0.26 & 2.32 & 0.22 & $\mathrm{G}$ & 1.00 & 0.40 \\
\hline Commodity-specific demand & 1.48 & 0.26 & 5.87 & 0.04 & $\mathrm{G}$ & 1.00 & 0.40 \\
\hline Commodity supply & 4.05 & 0.46 & 2.36 & 0.67 & $\mathrm{G}$ & 1.00 & 0.40 \\
\hline
\end{tabular}

Notes: Cols. (1) lists model parameters. Cols. (2)-(3) and Cols. (4)-(5) show the mode and the standard deviation (Std) of the posterior distributions of EA parameters and of US parameters, respectively. Cols. (6) (labelled 'Distrib.') indicates the prior distribution function (B: Beta distribution; G: Gamma distribution; N: Normal distribution). Identical priors are assumed for EA and US parameters. The commodity-specific demand shocks are assumed to follow AR(2) processes with first- and second-order autoregressive parameters $\rho_{1}$ and $\rho_{2}$. 


\section{DATA APPENDIX}

\section{Data sources}

Data for the EA (quarterly national accounts, fiscal aggregates, quarterly interest and exchange rates) are taken from Eurostat. Corresponding data for the US come from the Bureau of Economic Analysis (BEA) and the Federal Reserve. EA and US imports of industrial supplies from RoW are based on BEA data and on Eurostat Comext data. RoW series are constructed on the basis of the IMF International Financial Statistics (IFS) and World Economic Outlook (WEO) databases.

\section{Constructing of data series for RoW variables}

Series for GDP and prices in the RoW starting in 1999 are constructed on the basis of data for the following 58 countries: Albania, Algeria, Argentina, Armenia, Australia, Azerbaijan, Belarus, Brazil, Bulgaria, Canada, Chile, China, Colombia, Croatia, Czech Republic, Denmark, Egypt, Georgia, Hong Kong, Hungary, Iceland, India, Indonesia, Iran, Israel, Japan, Jordan, Korea, Lebanon, Libya, FYR Macedonia, Malaysia, Mexico, Moldova, Montenegro, Morocco, New Zealand, Nigeria, Norway, Philippines, Poland, Romania, Russia, Saudi Arabia, Serbia, Singapore, South Africa, Sweden, Switzerland, Syria, Taiwan, Thailand, Tunisia, Turkey, Ukraine, United Arab Emirates, United Kingdom, and Venezuela. The RoW data are annual data from the IMF International Financial Statistics (IFS) and World Economic Outlook (WEO) databases.

For details about the construction of RoW aggregates, see the Not-for-Publication Appendix.

\section{List of observables}

The estimation uses the time series information for 60 endogenous variables and initial values for additional 4 variables. The observables are:

Total factor productivity: EA,US;

Population: EA, US, RoW;

Labor force participation rate: EA,US;

Net imports of industrial supplies (from RoW): EA,US;

Price of imports of industrial supplies (from RoW): EA,US;

Change in inventories (residually computed): EA,US;

Trade balance of Services (residually computed as difference of trade balance of goods and services and trade balance of goods): EA,US;

GDP deflator: EA, US, RoW;

Real GDP: EA, US, RoW;

CPI deflator (divided by GDP deflator): EA,US;

Total investment (private+public) deflator (divided by GDP deflator): EA,US;

Exports (goods) deflator (divided by GDP deflator): EA,US;

Imports (goods) deflator (divided by GDP deflator): EA,US;

Total Hours: EA,US;

Nominal interest rate: EA,US, RoW;

Government consumption (as a share of GDP): EA,US;

Government investment (as a share of GDP): EA,US;

Transfers (as a share of GDP): EA,US;

Government debt (as a share of GDP), computed as cumulative sum of budget deficits: EA,US;

Government investment deflator (divided by GDP deflator): EA,US;

Government consumption deflator (divided by GDP deflator): EA,US;

Private consumption (as a share of GDP): EA,US;

Total investment, private and public (as a share of GDP): EA,US;

Wage bill (as a share of GDP): EA,US;

Exports (goods) (as a share of GDP): EA,US;

Gov't interest payments (as a share of GDP): EA,US;

Stock of physical capital (only initial value used): EA,US;

Oil price (Brent) in US dollars;

Nominal exchange rate Euro/Dollar;

Nominal effective exchange rate, EA;

Net Foreign Assets (as a share of GDP) (only initial value used): EA,US. 